\title{
Association between Sickle Cell Crisis and Other Types of Hemoglobin among Sudanese Children with Sickle Cell Anemia
}

\author{
Arwa Abdelbagi Mohammed ${ }^{1, *}$, Fathelrahman Mahadi Hassan², Abdelgadir Ahmed Abdelgadir ${ }^{1}$, \\ Amged Hussein Abdelrhman ${ }^{1}$ \\ ${ }^{1}$ Department of Hematology and Immunohematology, Omdurman Islamic University, Sudan. \\ ${ }^{2}$ Department of Clinical Laboratory Sciences, Collage of Applied Medical Science, Imam Abdulrahman Bin Faisal Universitym, \\ Dammam, KSA.
}

How to cite this paper: Arwa Abdelbagi Mohammed, Fathelrahman Mahadi Hassan, Abdelgadir Ahmed Abdelgadir, Amged Hussein Abdelrhman. (2021) Association between Sickle Cell Crisis and Other Types of Hemoglobin among Sudanese Children with Sickle Cell Anemia. International Journal of Clinical and Experimental Medicine Research, 5(2), 166-184.

DOI: 10.26855/ijcemr.2021.04.011

Received: February 13, 2021

Accepted: March 15, 2021

Published: April 7, 2021

*Corresponding author: Arwa Abdelbagi Mohammed, PhD Student, Department of Hematology and Immunohematology, Omdurman Islamic University, Sudan.

Email: arwabagi@gmail.com

\begin{abstract}
Background: Sickle cell anemia (SCA) is a common genetic disorder that causes considerable morbidity and mortality throughout the world. The study was performed in 82 Sudanese participants with sickle cell disease as study population with both sexes, age (2-12 years). Materials and Methods: Venous blood was collected using sterile disposable plastic syringe after cleaning the vein puncture area with $70 \%$ ethanol, the blood was added to the EDTA and gently mixed, then CBC was performed using (Sysmex-3000 plus) and (Electrophoresis) was done. Results: The results of this study show that most patients had raised level of hemoglobin $\mathrm{F}$ according to gender found that there were 43 males and 28 females had raised level of $\mathrm{HbF}, 7$ males and 2 females were normal, and $36 \%$ of patients had raised level of HbA2 in both gender (20 males) (10 females). Conclusion: $\mathrm{HbF}$ in sickle cell anemia patients was found to be $85.3 \%$ (raised), HbS in sickle cell anemia patients was found to be $100 \%$ (raised) and $\mathrm{HbA} 2$ in sickle cell anemia patients was found to be $30.5 \%$ (Normal).
\end{abstract}

\section{Keywords}

Sudanese Children, Sickle Cell Crisis, other Types of Hemoglobin

\section{Introduction}

Sickle cell anaemia (SCA) is a common genetic disorder that causes considerable morbidity and mortality throughout the world. SCA an amino acid substitution of valine for glutamic acid at position 6 of the $\beta$-globin chain, which results in the polymerization of haemoglobin upon DE oxygenation, leading to deformed dense red blood cells. The predominant pathophysiological feature of SCA is vaso-occlusion, which leads to acute and chronic complications such as painful crises, acute chest syndrome and strokes. Patients with SCA have a markedly decreased life expectancy and their quality of life is greatly compromised by their disease [1] [2]. In 1910, Dr James Herrick working in Chicago, USA, reported "Peculiar elongated and sickle shaped red blood corpuscles in a case of severe anaemia" [2] [3] [4]. The inherited disease was subsequently called SCA, and has continued to attract the attention of medical scientists to the present day. SCA includes homozygous (Hb SS) sickle cell disease and compound heterozygous states such as sickle cell haemoglobin C (Hb SC) disease, sickle cell thalassemia [5] [6] [7]. Haemoglobin S becomes polymerized and becomes poorly soluble when the oxygen tension is lowered and red 
cells that contain this haemoglobin become distorted and rigid. SCD occurs when an individual is homozygous for the sickle cell mutation or is a compound heterozygote for sickle haemoglobin and $\beta$-thalassemia [8] [9] [10].

\section{Materials and Methods}

Study Participants: The study was performed in 82 Sudanese patients with sickle cell disease as study population with both sexes, age (3-12 years).

\section{Sample preparation and methods:}

Venous blood was collected using sterile disposable plastic syringe after cleaning the vein puncture area with $70 \%$ ethanol, the blood was added to the EDTA and gently mixed.

\section{Automated hematology analyzer (BC-3000 plus) technique:}

The Coulter principle is based on the following: particles suspended in an isotonic diluent, when drawn through an aperture which has an electric current flowing through it was caused a measurable drop in voltage which is proportional to the size of the particle passing through the aperture is constant the particle can be quantified per unit volume. This is also called electrical impedance.

\section{Hemoglobin electrophoresis:}

The CAPILLARYS 2 FLEX-PIERCING instrument uses the principle of capillary electrophoresis in free solution. With this technique, charged molecules are separated by their electrophoretic mobility in an alkaline buffer with a specific $\mathrm{pH}$. Separation also occurs according to the electrolyte $\mathrm{pH}$ and electro osmotic flow.

\section{Statistical Analysis:}

Statistical assessment was carried out with statistical package for social sciences (SPSS) version 17.0 for windows statistical software.

\section{Results}

The results were compared according to the objectives of the study as illustrated below: Table 1 shows the distribution of gender among study population (51) of patients (62.2\%) are male, (31) of patients are female (37.8\%), Table 2 shows distribution of age among the study population into two groups (2-7) 50\%, (8-12) 50\%, Table 3 shows distribution of hemoglobin according to gender and severity of anemia, found 44 male suffering from severe anemia and 7 male moderate anemic, 82 females suffering from severe anemia and 3 females were moderate anemic, Table 1 shows distribution of red blood cell according to gender found that 49 males and 31 females had erythropenia, 2 males were normal, Table 2 shows distribution of white blood cell according to gender found that 27 males and 23 females suffering from leukocytosis and 24 males and 8 females were normal, Table 3 shows distribution of platelets according to gender 27 males and 15 females had thrombocytosis, 3 males and 2 females had thrombocytopenia, and 21 males and 14 females were normal, Table 4 shows distribution of hemoglobin F according to gender found 43 males and 28 females had raised level of HbF, 1 male and 1 female had decreased level of $\mathrm{HbF}, 7$ males and 2 females were normal. Table 5 shows distribution of hemoglobin A2 according to gender found that 20 males and 10 females had raised level of $\mathrm{HbA} 2,1$ female had decreased level of HbA2, 31 males and 20 females were normal, Table 6 shows distribution of hemoglobin according to age found that (2-7 years) 35 had severe anemia and 6 had moderate anemia, and in the other age group (8-12 years) 37 had severe anemia and 4 had moderate anemia, Table 7 shows distribution of red blood cell according to gender found that in both age group (2-7 years) and (8-12 years) 40 had erythropenia and 1 was normal. Table 8 shows distribution of white blood cell according to age found that in both age groups (2-7 years) and (8-12) 25 patients had leukocytosis and 16 were. Table 9 shows distribution of platelets according to age found that age group (2-7years) 22 patients had thrombocytosis, 2 patients had thrombocytopenia and 17 patients were normal, the other age group (8-12 years) 20 patients had thrombocytosis, 3 patients thrombocytopenia and 18 were normal. Table 10 shows distribution of HbF according to age found that the age group (2-7 years) 33 patients had raised HbF level, 2 patients had decreased level of $\mathrm{HbF}$ and 6 patients were normal, in the other age group (8-12years) 38 patients had raised level of $\mathrm{HbF}$ and 3 patients were normal. Table 11 shows distribution of HbA2 according to the age found that the age group (2-7 years) there was 15 patients had raised HbA2 level and 26 patients were normal in the other age group (8-12 years), there was 15 patients had raised HbA2 level, 1 patient had decreased HbA2 level and 25 patients were normal. Table 12 shows correlation between hemoglobin and red blood cells found that in 72 patients that had severe anemia there was 71 patients had erythrocytopenia and 1 patient was normal, and in 10 patients that had moderate anemia there was 9 patients had erythrocytopenia and 1 patient was normal. Table 13 shows comparison between hemoglobin and white blood cells found that in 72 patients that had severe anemia there was 47 patients had leukocytosis and 25 
patients were normal, and in 3 patients that had moderate anemia there was 9 patients had leukocytosis and 7 patients were normal.

Table 14 shows correlation between hemoglobin and platelets found that in 72 patients had severe anemia there was 36 patients had thrombocytosis, 4 patients had thrombocytopenia and 32 were normal, and in 10 patients that had moderate anemia there was 6 patients had thrombocytosis, 1 patient had thrombocytopenia and 3 patientd were normal. Table 15 shows comparison between hemoglobin and $\mathrm{HbF}$ found that in 72 patients that had severe anemia there was 62 patients had raised $\mathrm{HbF}$ level, 2 patients had decreased $\mathrm{HbF}$ level and 8 patient were normal, and in 10 patients that had moderate anemia there was 9 patients had raised $\mathrm{HbF}$ level and 1 patient was normal. Table 16 shows comparison between hemoglobin and HbA2 found that in 72 patients that had severe anemia there was 28 patients had raised HbA2 level, 1 patients had decreased HbA2 level and 43 patients were normal, and in 10 patients that had moderate anemia there was 2 patients had raised HbA2 level and 8 patients were normal. Table 17 shows mean and SD of $\mathrm{Hb} \mathrm{F}, \mathrm{Hb} \mathrm{S}$ and HbA2 male (2.71 \pm 0.701$)$ female $(2.84 \pm 0.523),(2.0 \pm 0.0)$ for both genders and male (1.78 \pm 0.986$)$ female (1.68 \pm 0.945$)$ respectively.

Figure 1 shows scatter plot of correlation between hemoglobin\% and HbF\%, Figure 2 shows scatter plot of correlation between hemoglobin\% and HbS\%, Figure 1 shows scatter plot of correlation between hemoglobin\% and age, Figure 2 shows scatter plot of correlation between hemoglobin\% and HbA2\%.

Table 1. Distribution of Gender among study population

\begin{tabular}{ccc} 
& Frequency & Percent \\
\hline male & 51 & 62.2 \\
female & 31 & 37.8 \\
Total & 82 & 100.0 \\
\hline
\end{tabular}

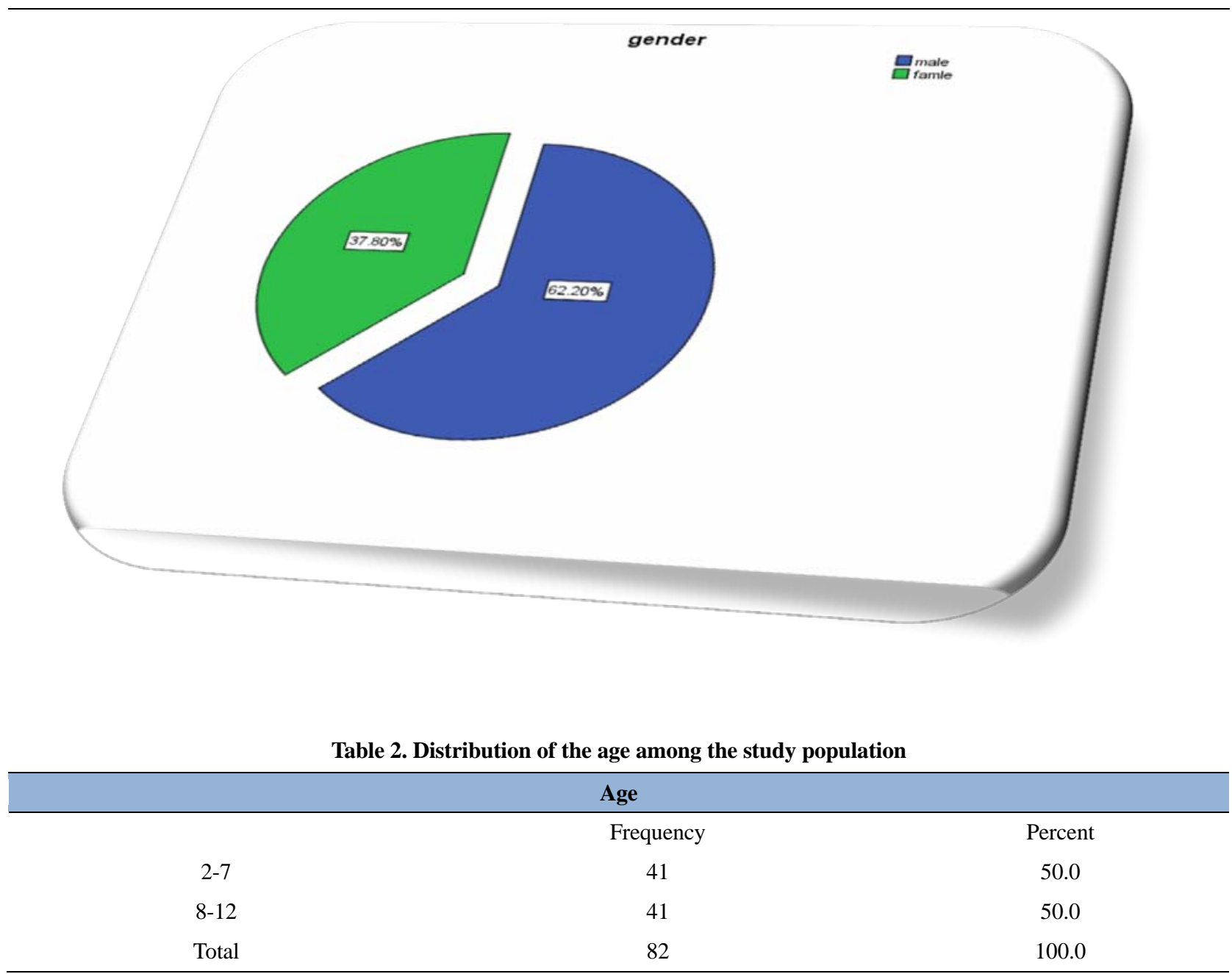




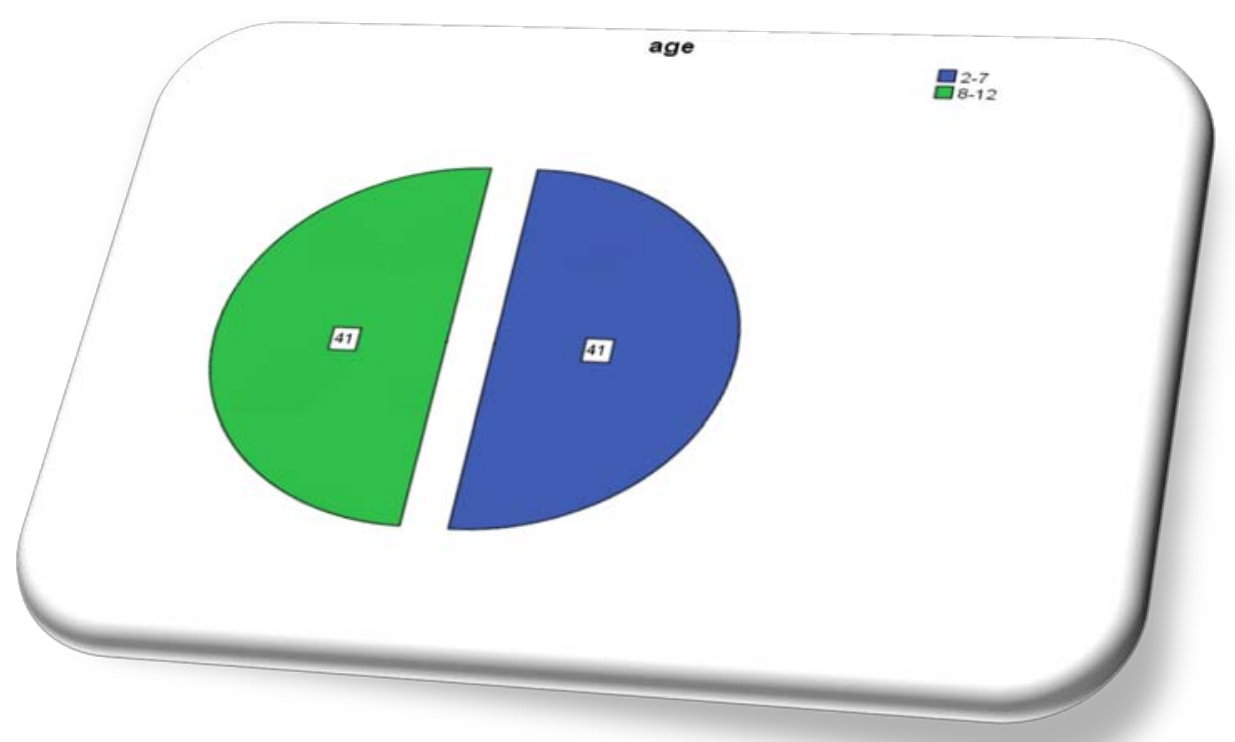

Table 3. Distribution of hemoglobin according to gender

\begin{tabular}{|c|c|c|c|c|}
\hline \multicolumn{5}{|c|}{ gender * Hemoglobin } \\
\hline \multicolumn{5}{|c|}{ Count } \\
\hline & & \multicolumn{2}{|c|}{ Hemoglobin \% } & \multirow{2}{*}{ Tota } \\
\hline \multirow{4}{*}{ Gender } & & severe anemia & anemia & \\
\hline & Male & 44 & 7 & 51 \\
\hline & female & 28 & 3 & 31 \\
\hline & & 72 & 10 & 82 \\
\hline
\end{tabular}

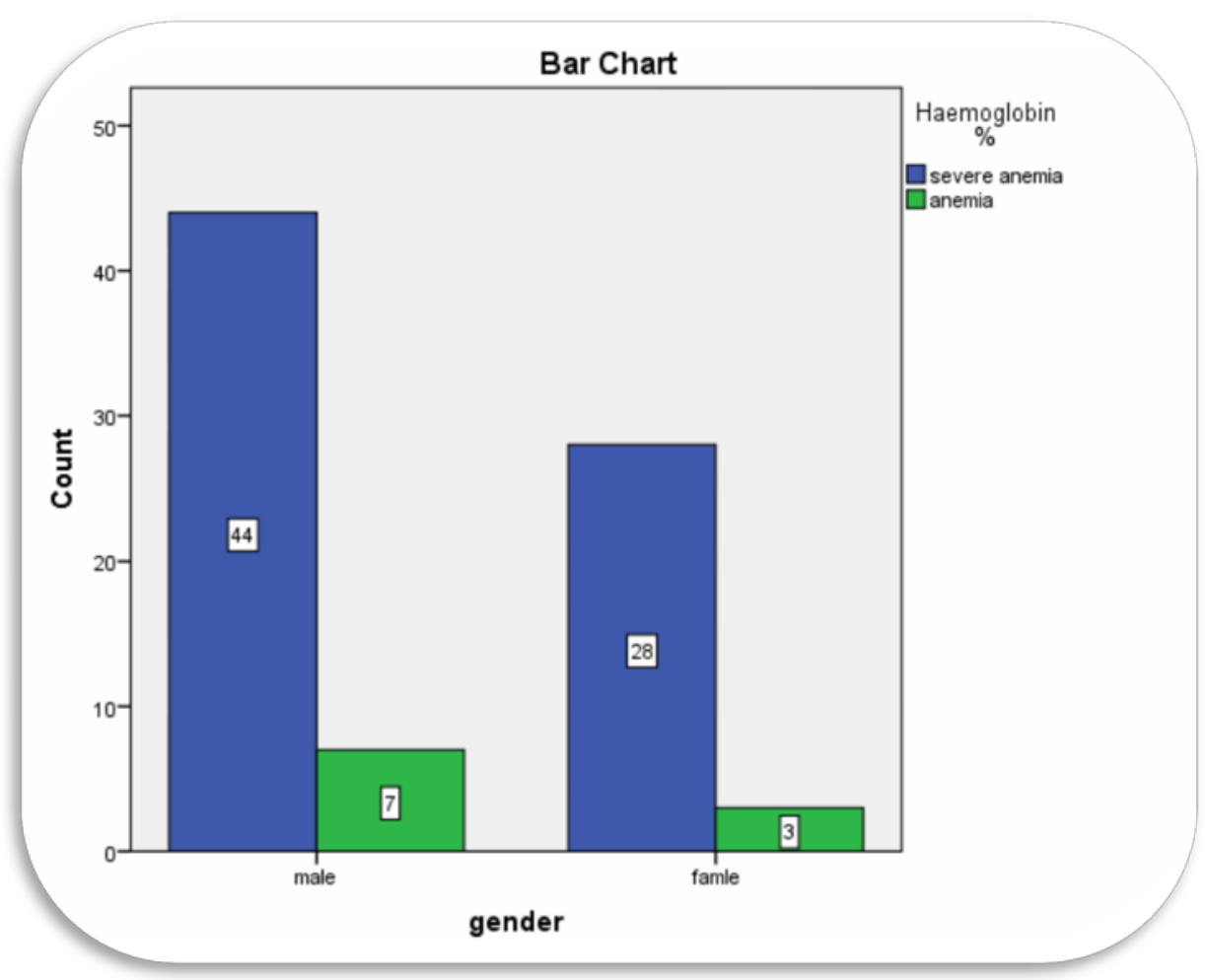


Table 4. Distribution of red blood cell according to gender

\begin{tabular}{|c|c|c|c|c|}
\hline \multicolumn{5}{|c|}{ gender $*$ red blood cells } \\
\hline & & \multicolumn{2}{|c|}{ Count } & \multirow{3}{*}{ Total } \\
\hline & & \multicolumn{2}{|c|}{ red blood cells } & \\
\hline \multirow{4}{*}{ Gender } & \multirow[b]{2}{*}{ Male } & $4-5.5$ & less than 4 & \\
\hline & & 2 & 49 & 51 \\
\hline & female & 0 & 31 & 31 \\
\hline & & 2 & 80 & 82 \\
\hline
\end{tabular}

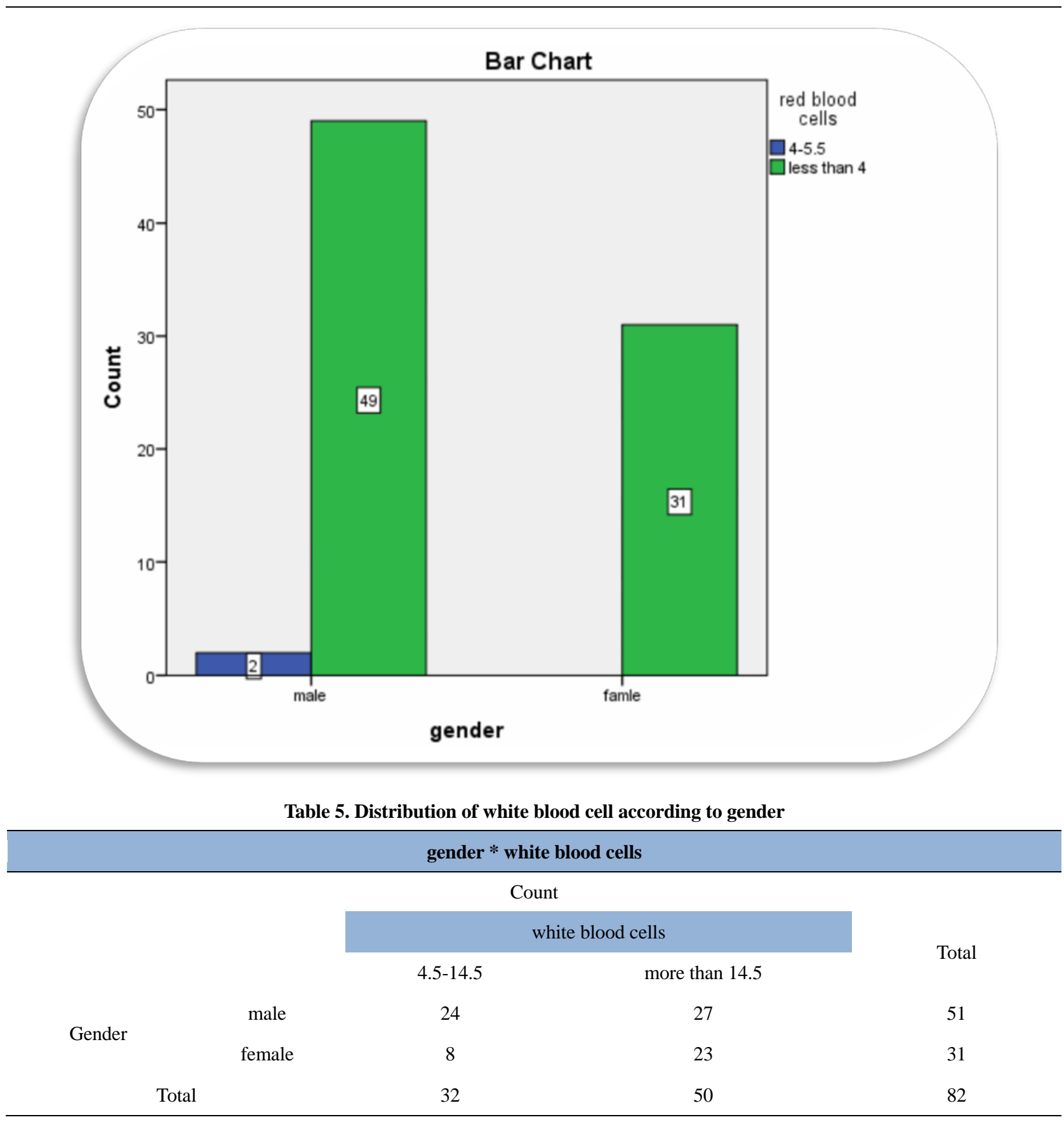




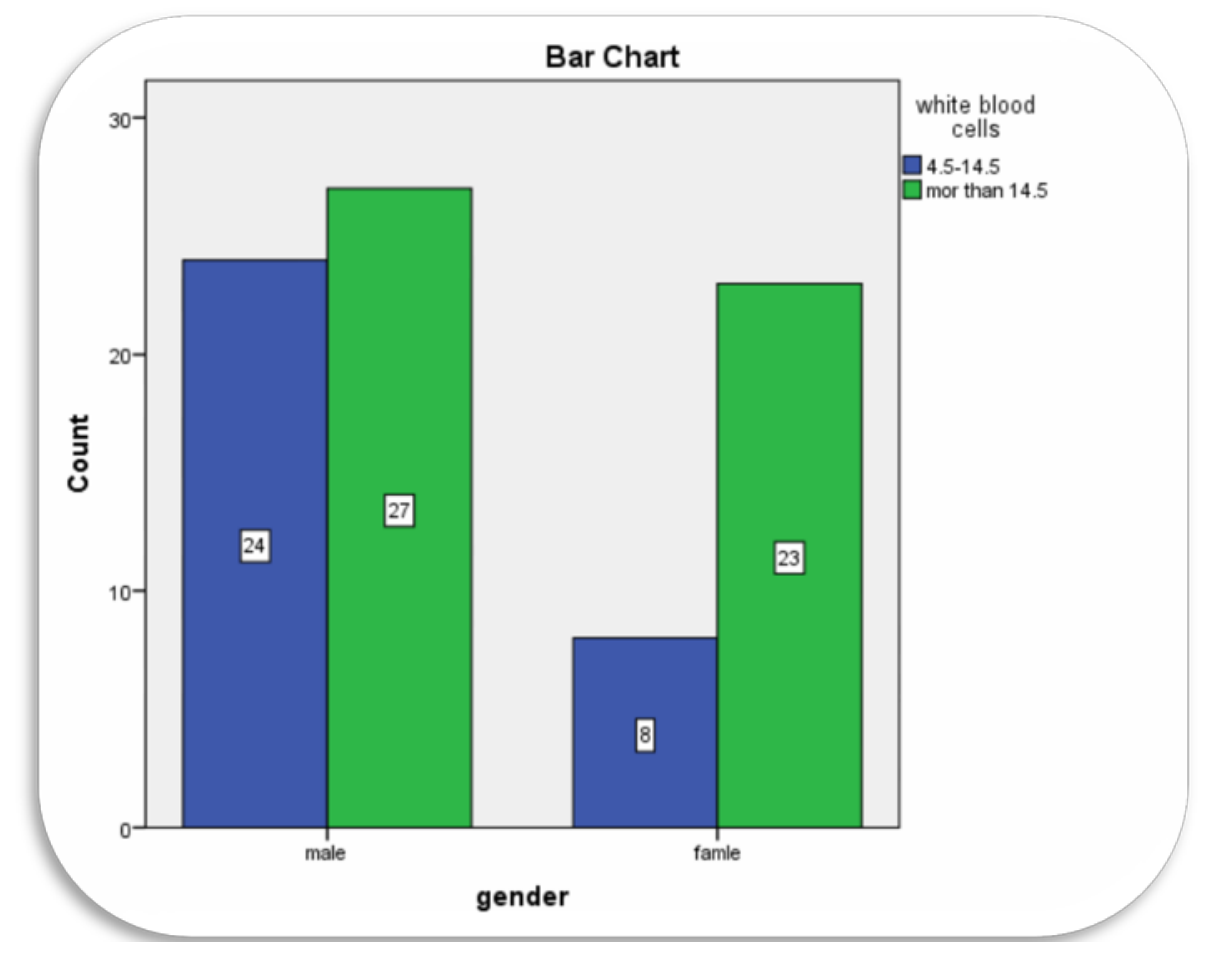

Table 6. Distribution of platelets according to gender

\begin{tabular}{|c|c|c|c|c|c|}
\hline \multicolumn{6}{|c|}{ gender * platelets } \\
\hline & & \multicolumn{3}{|c|}{ Count } & \multirow{3}{*}{ Tota } \\
\hline & & \multicolumn{3}{|c|}{ Platelets } & \\
\hline \multirow{3}{*}{ Gender } & & $150-400$ & less than 150 & more than 400 & \\
\hline & Male & 21 & 3 & 27 & 51 \\
\hline & Female & 14 & 2 & 15 & 31 \\
\hline \multicolumn{2}{|c|}{ Total } & 35 & 5 & 42 & 82 \\
\hline
\end{tabular}

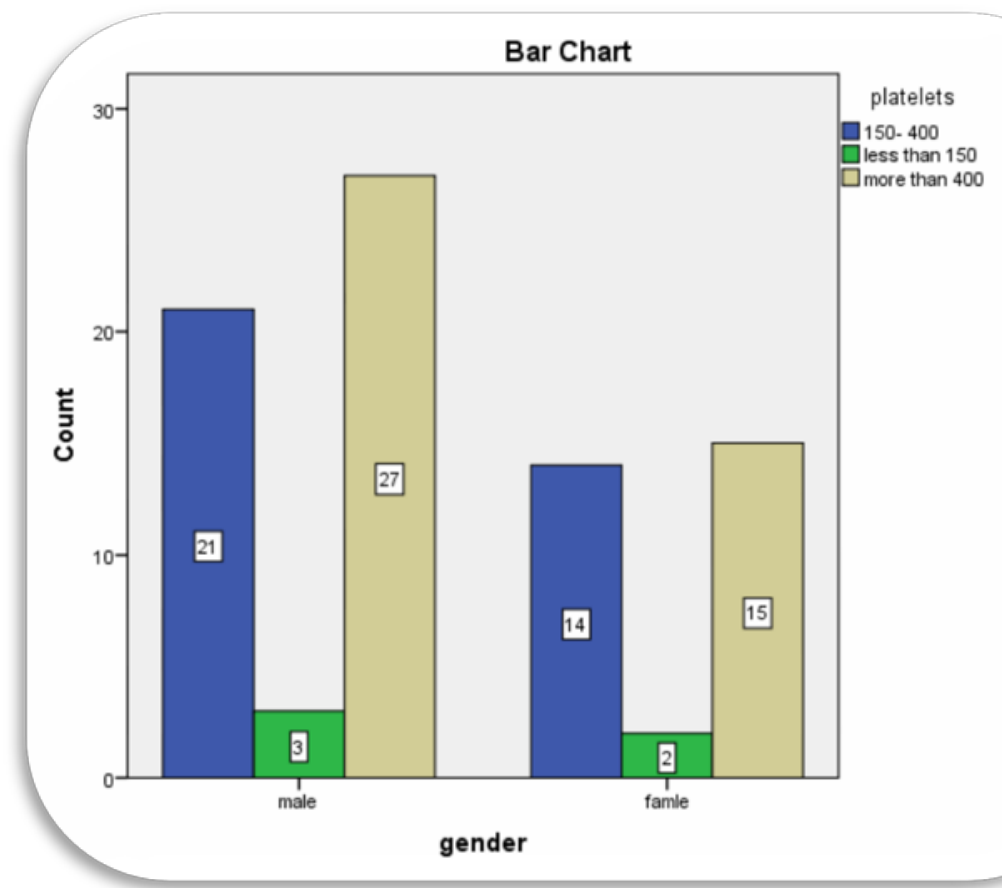


Table 7. Distribution of hemoglobin $F$ according to gender

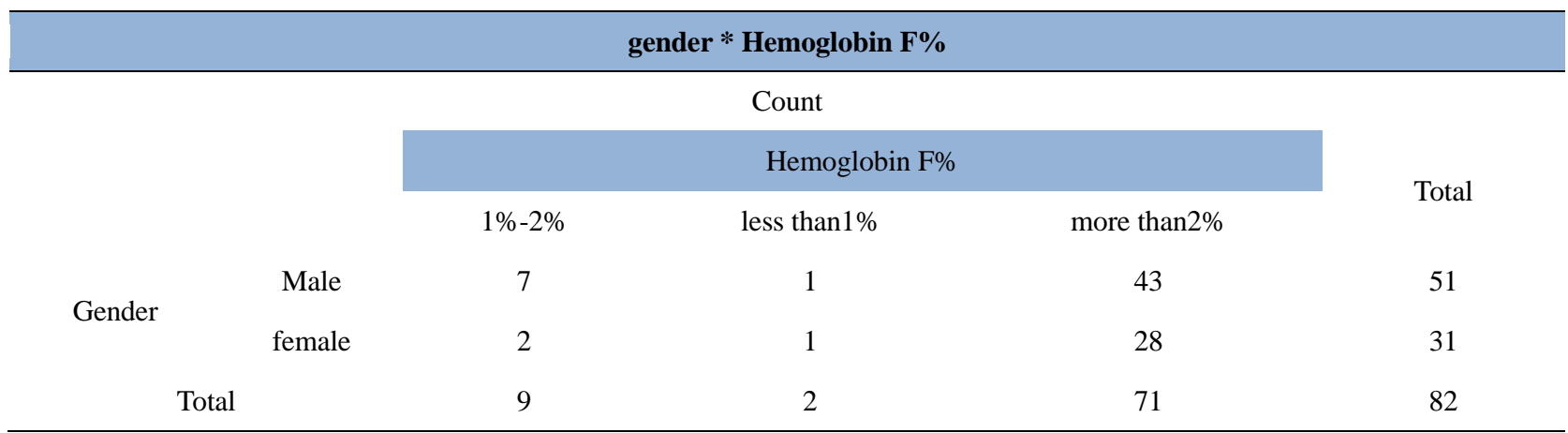

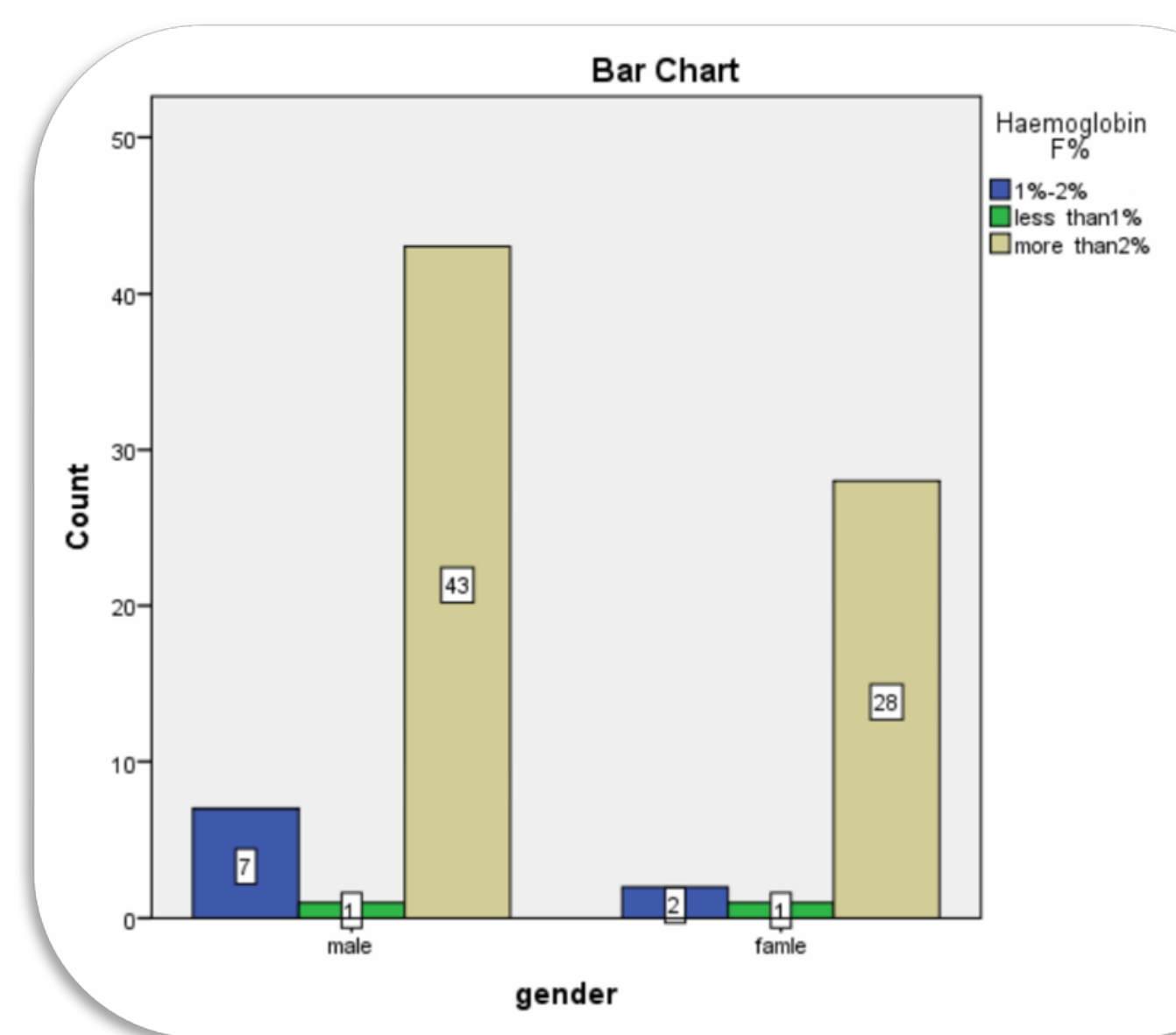

Table 8. Distribution of hemoglobin A2 according to gender

\begin{tabular}{|c|c|c|c|c|c|}
\hline \multicolumn{6}{|c|}{ gender * Hemoglobin A2\% } \\
\hline & & \multicolumn{3}{|c|}{ Count } & \multirow{3}{*}{ Tota } \\
\hline & & \multicolumn{3}{|c|}{ Hemoglobin A2\% } & \\
\hline \multirow{3}{*}{ Gender } & & $2 \%-3 \%$ & less than $2 \%$ & more than $3 \%$ & \\
\hline & Male & 31 & 0 & 20 & 51 \\
\hline & female & 20 & 1 & 10 & 31 \\
\hline \multicolumn{2}{|c|}{ Total } & 51 & 1 & 30 & 82 \\
\hline
\end{tabular}




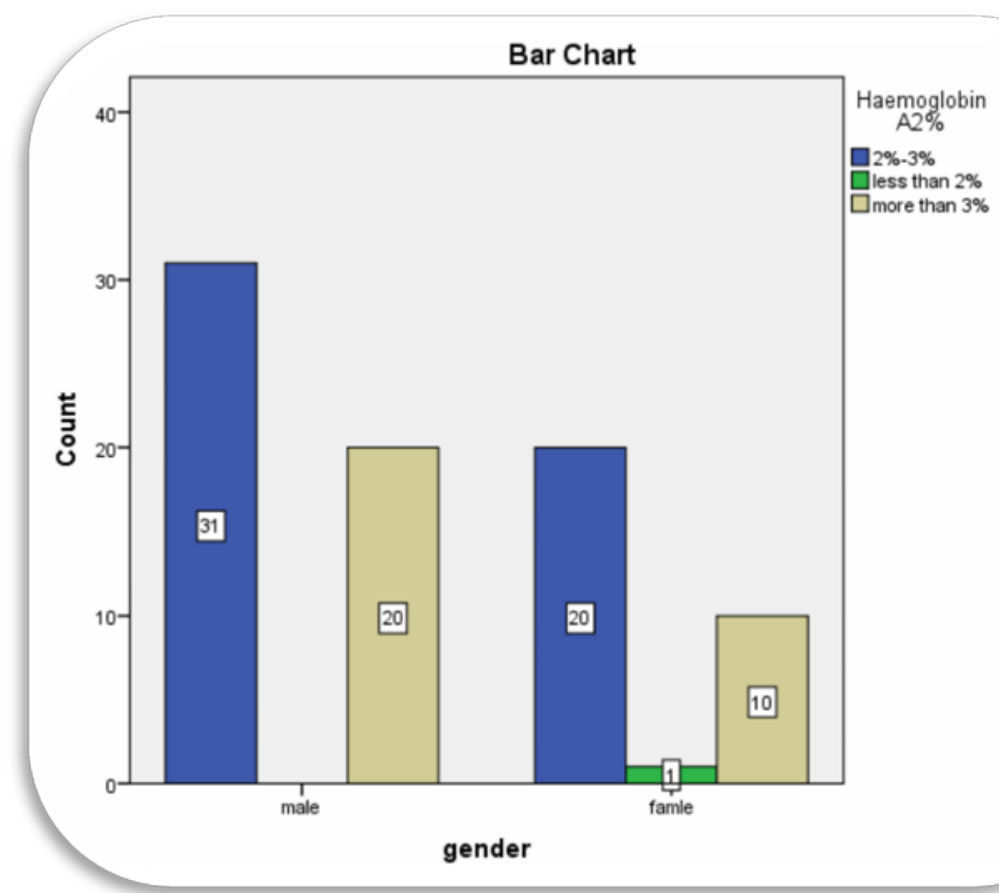

Table 9. Distribution of hemoglobin according to age

\begin{tabular}{|c|c|c|c|c|}
\hline \multicolumn{5}{|c|}{ age $*$ Hemoglobin $\%$} \\
\hline \multicolumn{5}{|c|}{ Count } \\
\hline & & \multicolumn{2}{|c|}{ Hemoglobin\% } & \multirow{2}{*}{ Total } \\
\hline \multirow{4}{*}{ Age } & & severe anemia & anemia & \\
\hline & $2-7$ & 35 & 6 & 41 \\
\hline & $8-12$ & 37 & 4 & 41 \\
\hline & & 72 & 10 & 82 \\
\hline
\end{tabular}

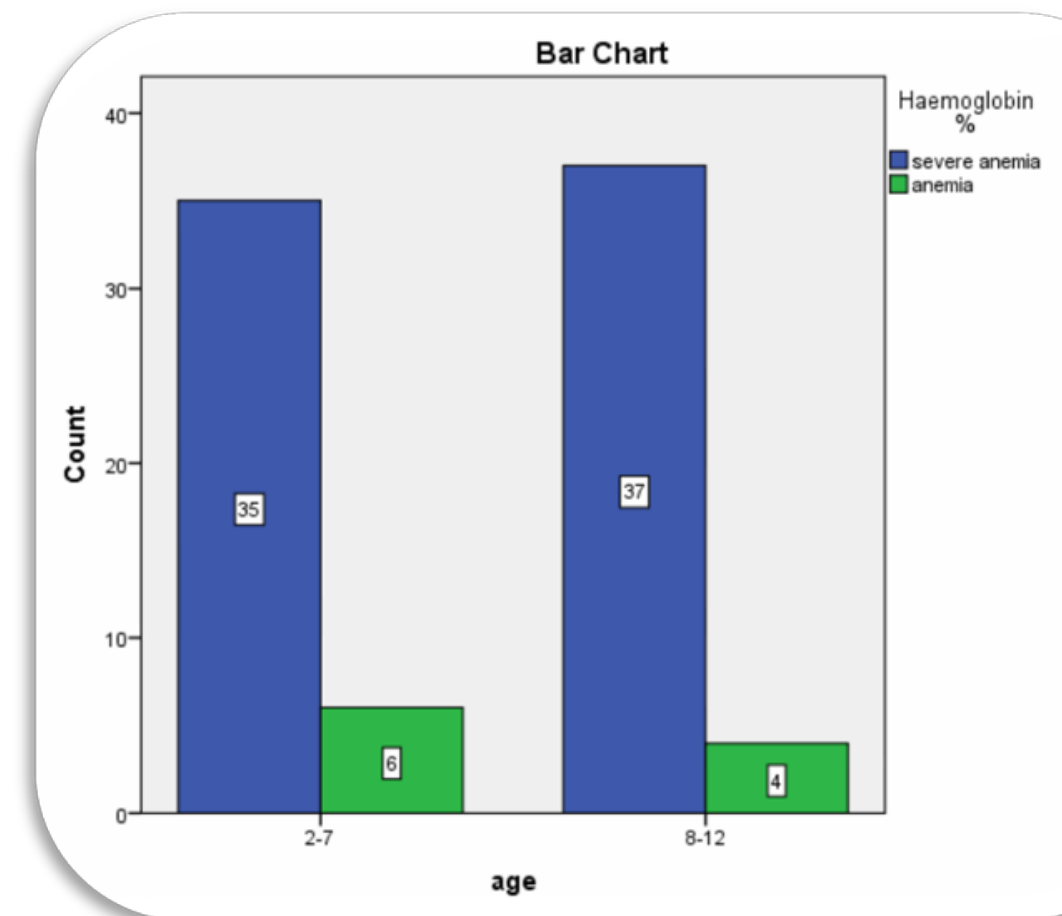


Table 10. Distribution of red blood cell according to age

\begin{tabular}{|c|c|c|c|c|}
\hline \multicolumn{5}{|c|}{ age * Red blood cells } \\
\hline & & \multicolumn{2}{|c|}{ Count } & \multirow{3}{*}{ Total } \\
\hline & & \multicolumn{2}{|c|}{ Red blood cells } & \\
\hline \multirow{4}{*}{ Age } & & $4-5.5$ & less than 4 & \\
\hline & $2-7$ & 1 & 40 & 41 \\
\hline & $8-12$ & 1 & 40 & 41 \\
\hline & & 2 & 80 & 82 \\
\hline
\end{tabular}

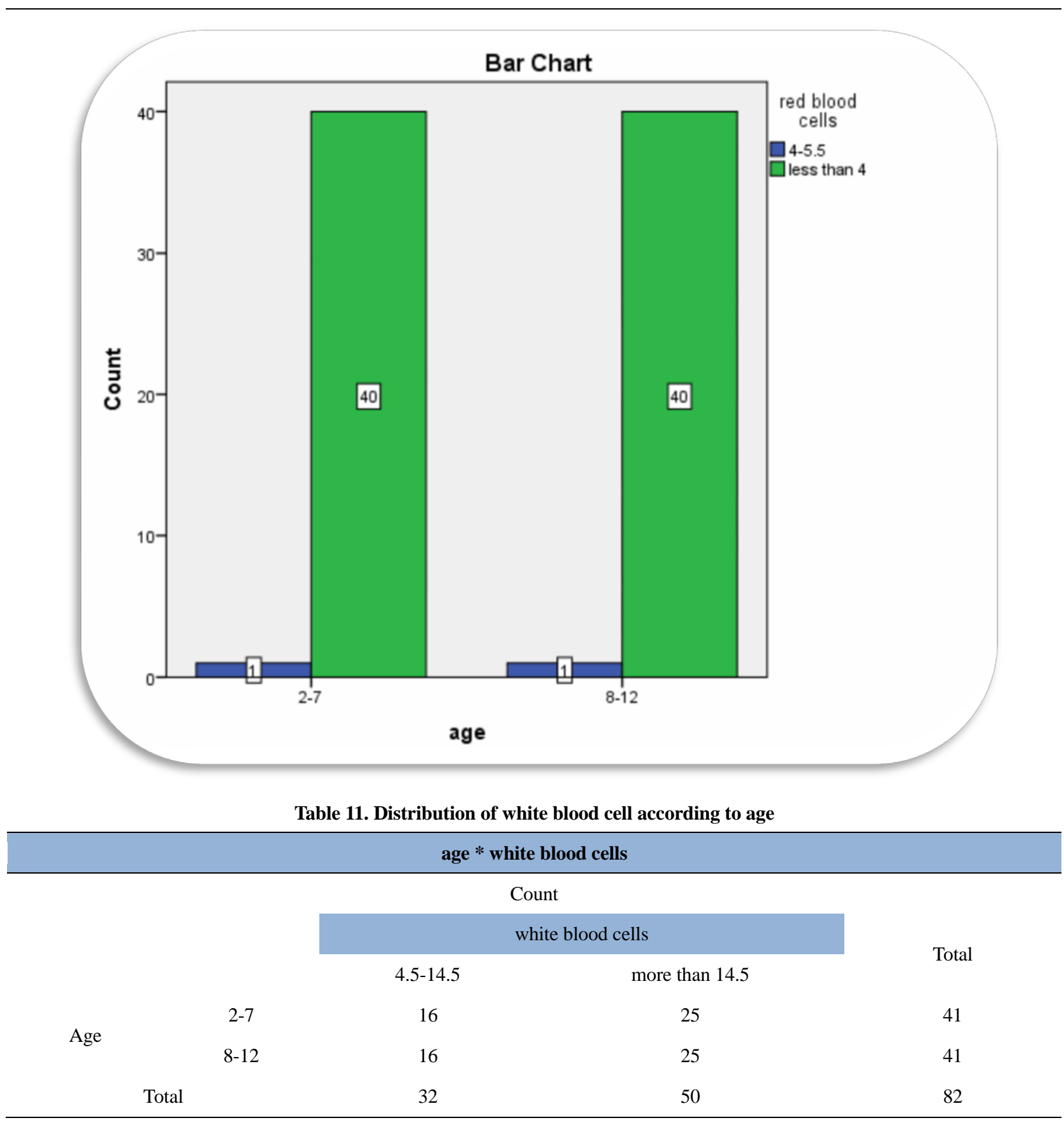




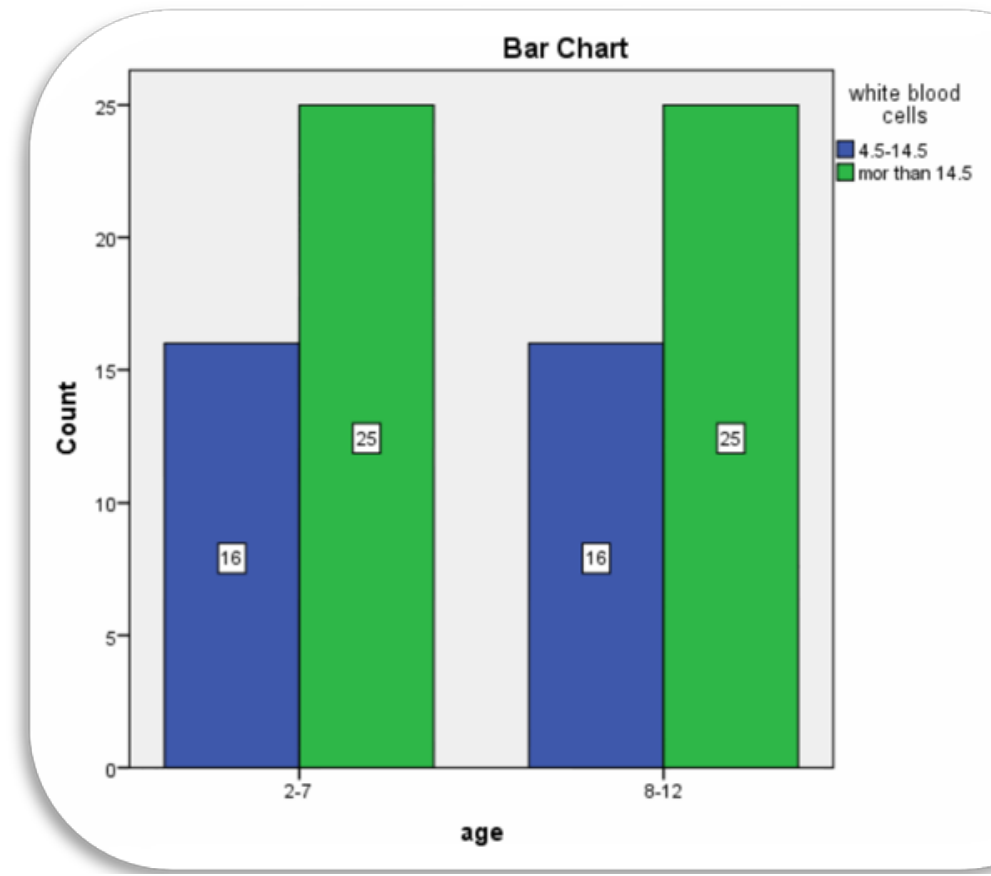

Table 12. Distribution of platelets according to age

\begin{tabular}{|c|c|c|c|c|c|}
\hline \multicolumn{6}{|c|}{ age * platelets } \\
\hline & & \multicolumn{3}{|c|}{ Count } & \multirow{3}{*}{ Tota } \\
\hline & & \multicolumn{3}{|c|}{ Platelets } & \\
\hline \multirow{3}{*}{ Age } & & $150-400$ & less than 150 & more than 400 & \\
\hline & $2-7$ & 17 & 2 & 22 & 41 \\
\hline & $8-12$ & 18 & 3 & 20 & 41 \\
\hline \multicolumn{2}{|c|}{ Total } & 35 & 5 & 42 & 82 \\
\hline
\end{tabular}

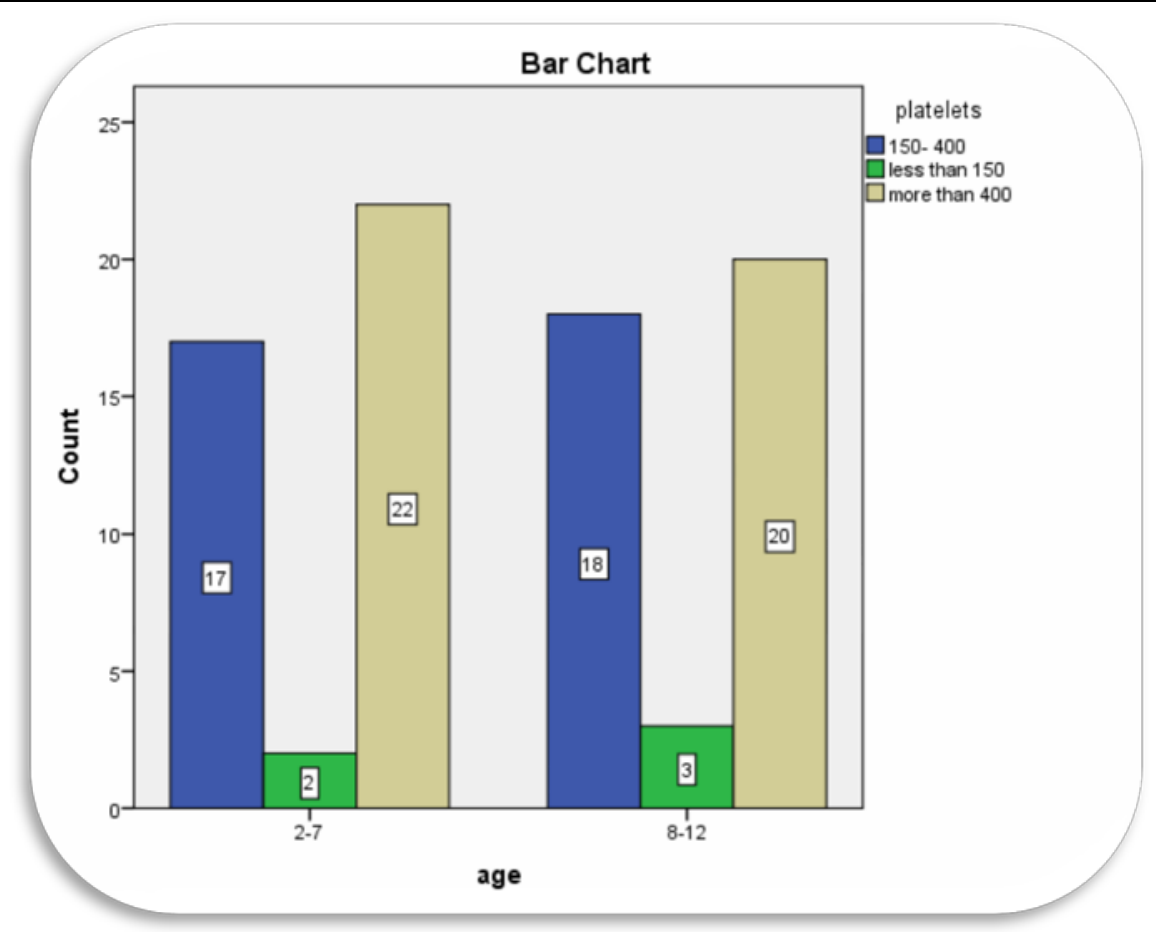


Table 13. Distribution of hemoglobin $F$ according to age

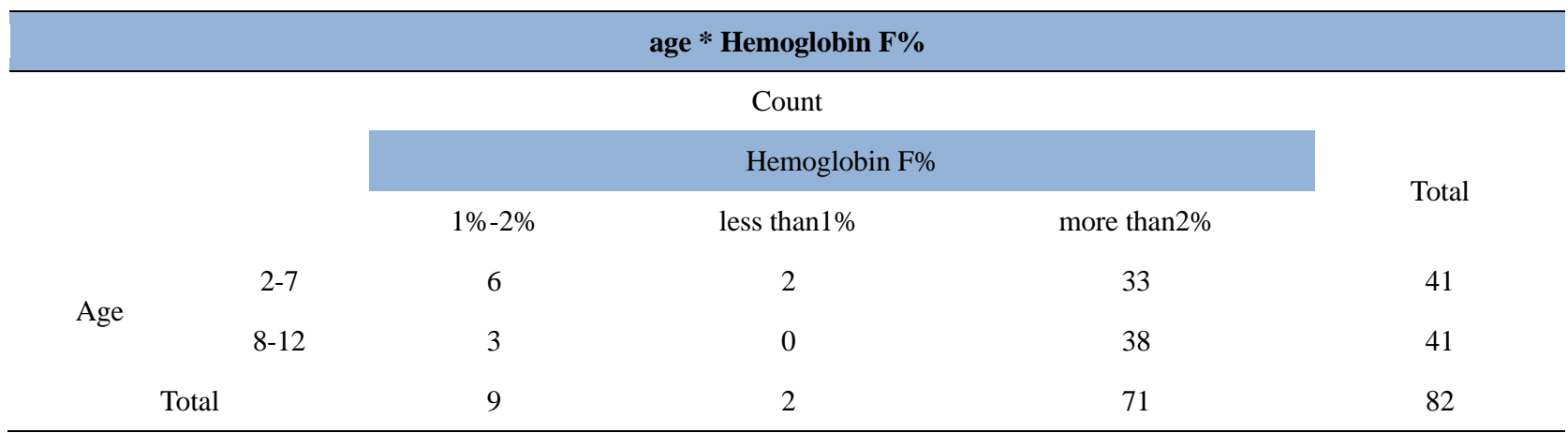

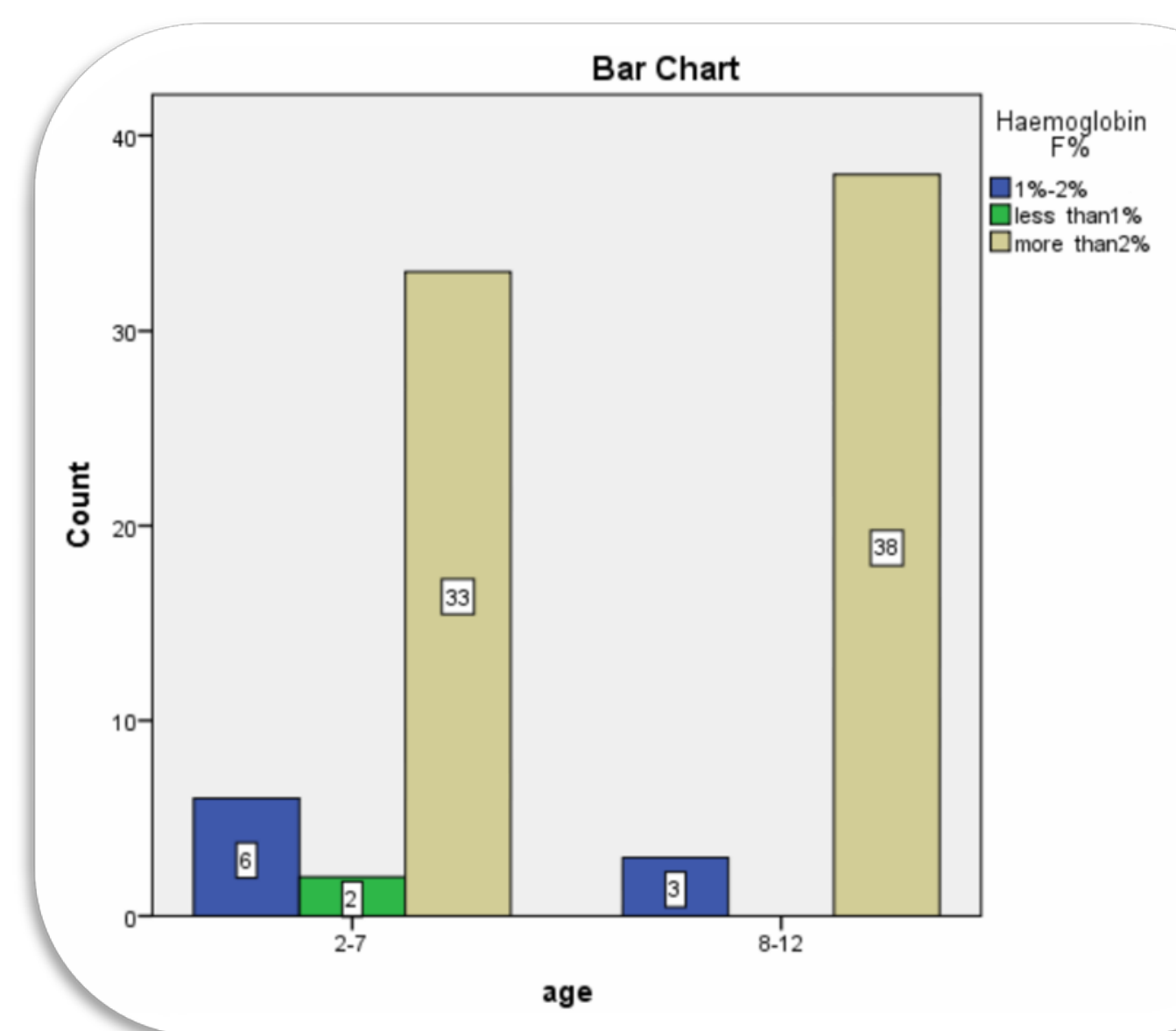

Table 14. Distribution of hemoglobin A2 according to age

\begin{tabular}{|c|c|c|c|c|c|}
\hline \multicolumn{6}{|c|}{ age * Hemoglobin A2\% } \\
\hline \multicolumn{6}{|c|}{ Count } \\
\hline & & \multicolumn{3}{|c|}{ Hemoglobin A2\% } & \multirow{2}{*}{ Tota } \\
\hline & & $2 \%-3 \%$ & less than $2 \%$ & more than $3 \%$ & \\
\hline \multirow{2}{*}{ Age } & $2-7$ & 26 & 0 & 15 & 41 \\
\hline & $8-12$ & 25 & 1 & 15 & 41 \\
\hline \multicolumn{2}{|c|}{ Total } & 51 & 1 & 30 & 82 \\
\hline
\end{tabular}




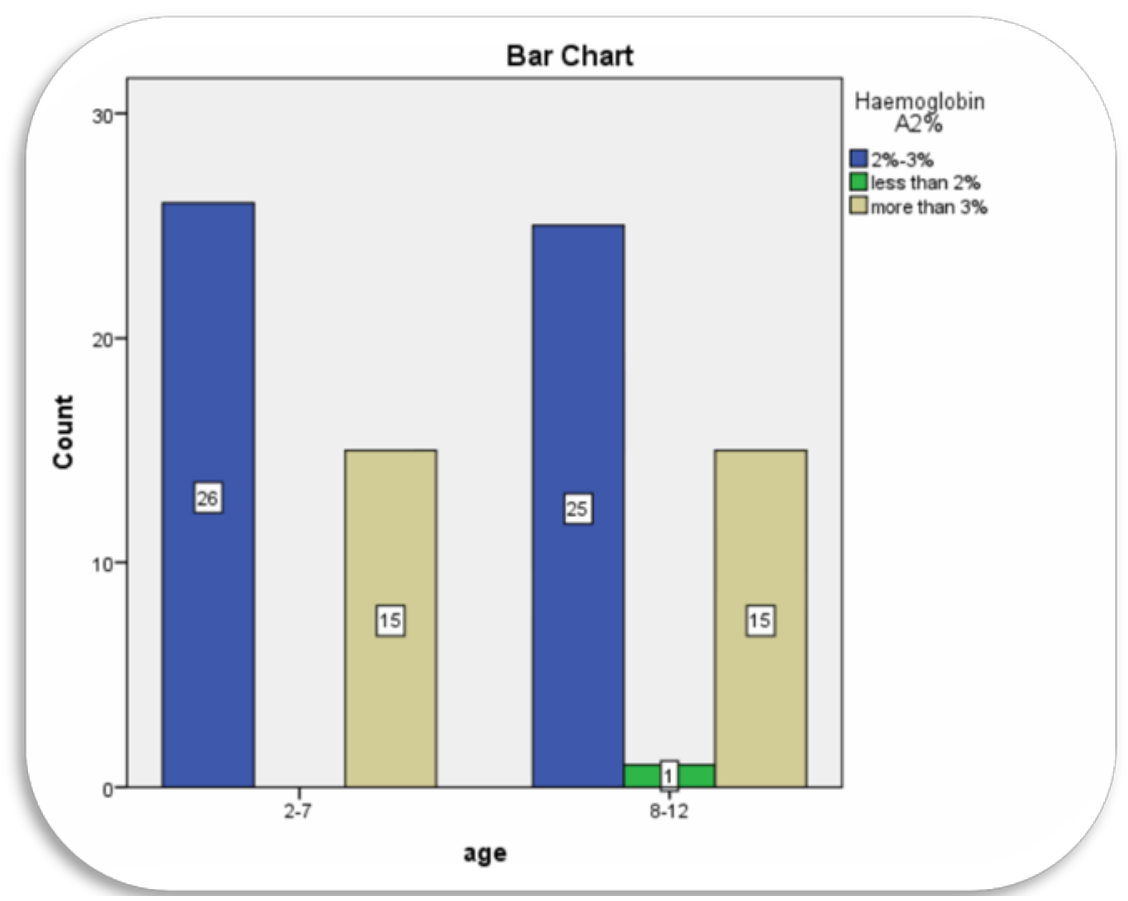

Table 15. Comparison between hemoglobin and red blood cell

\begin{tabular}{|c|c|c|c|c|}
\hline \multicolumn{5}{|c|}{ Hemoglobin $\% *$ Red blood cells } \\
\hline \multicolumn{5}{|c|}{ Count } \\
\hline & & \multicolumn{2}{|c|}{ Red blood cells } & \multirow{2}{*}{ Total } \\
\hline \multirow{4}{*}{ Hemoglobin\% } & \multirow{3}{*}{$\begin{array}{l}\text { severe anemia } \\
\text { anemia }\end{array}$} & $4-5.5$ & less than 4 & \\
\hline & & 1 & 71 & 72 \\
\hline & & 1 & 9 & 10 \\
\hline & & 2 & 80 & 82 \\
\hline
\end{tabular}

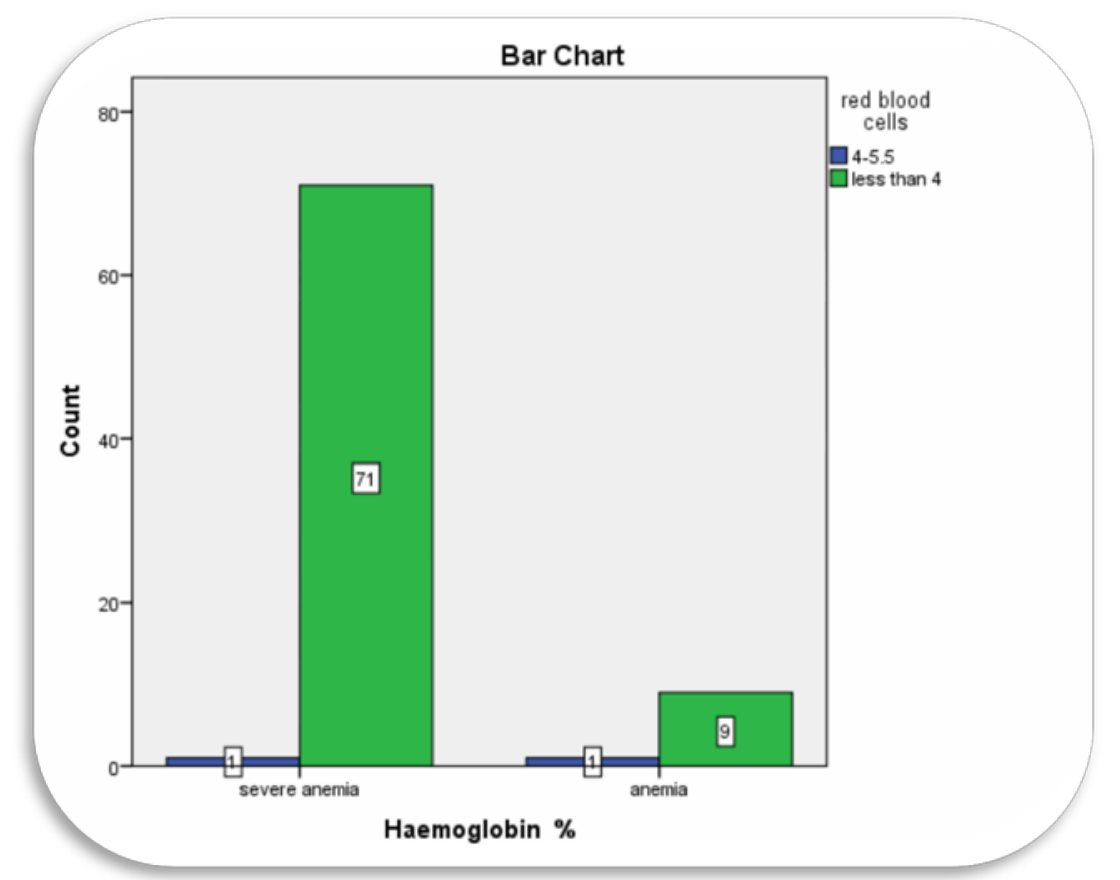


Table 16. Comparison hemoglobin and white blood cell

\begin{tabular}{|c|c|c|c|c|}
\hline \multicolumn{5}{|c|}{ Hemoglobin \%* white blood cells } \\
\hline & & \multicolumn{2}{|l|}{ Count } & \multirow{3}{*}{ Total } \\
\hline & & \multicolumn{2}{|c|}{ white blood cells } & \\
\hline \multirow{4}{*}{ Hemoglobin\% } & & 4.5-14.5 & more than 14.5 & \\
\hline & severe anemia & 25 & 47 & 72 \\
\hline & Anemia & 7 & 3 & 10 \\
\hline & & 32 & 50 & 82 \\
\hline
\end{tabular}

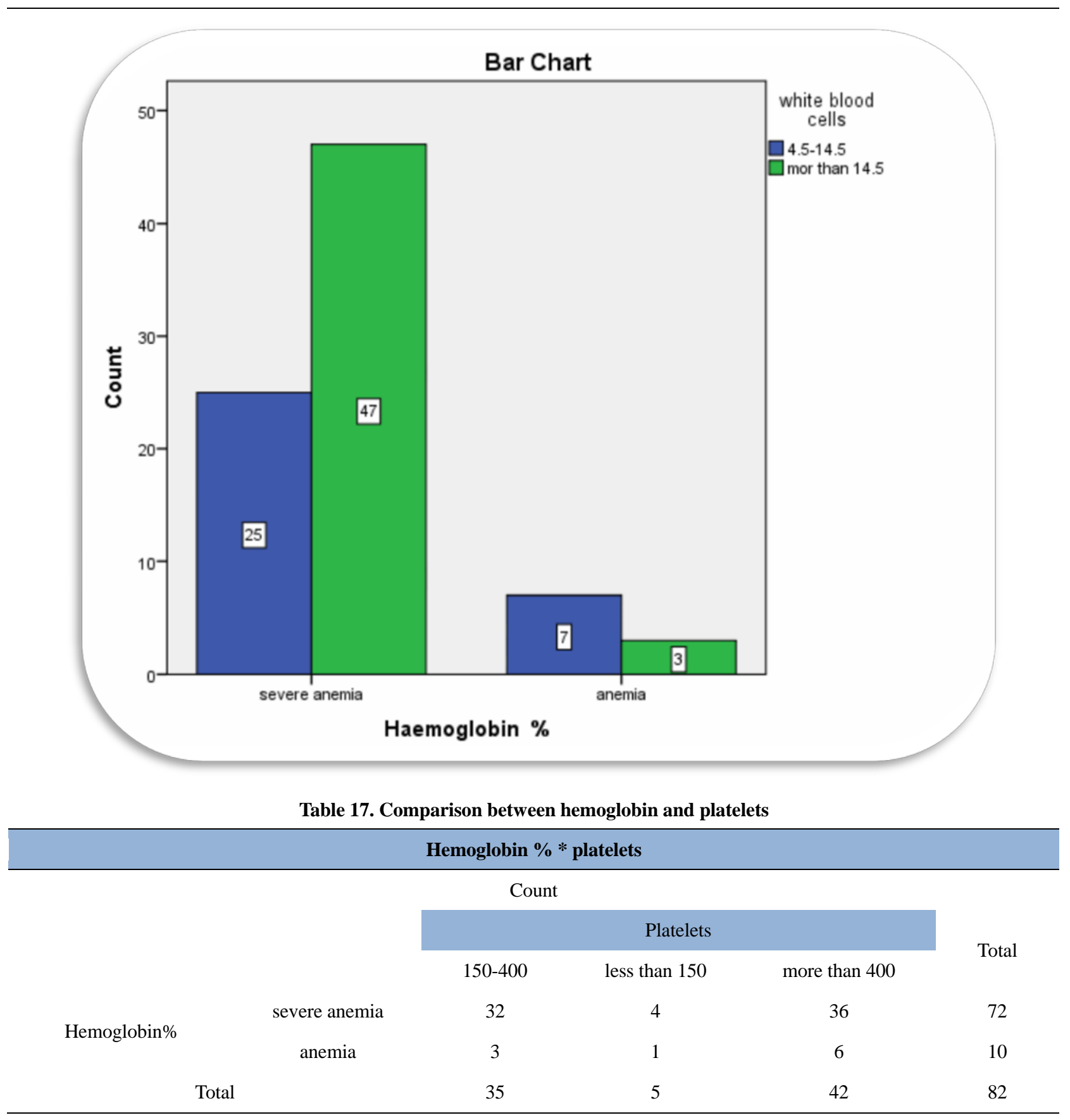




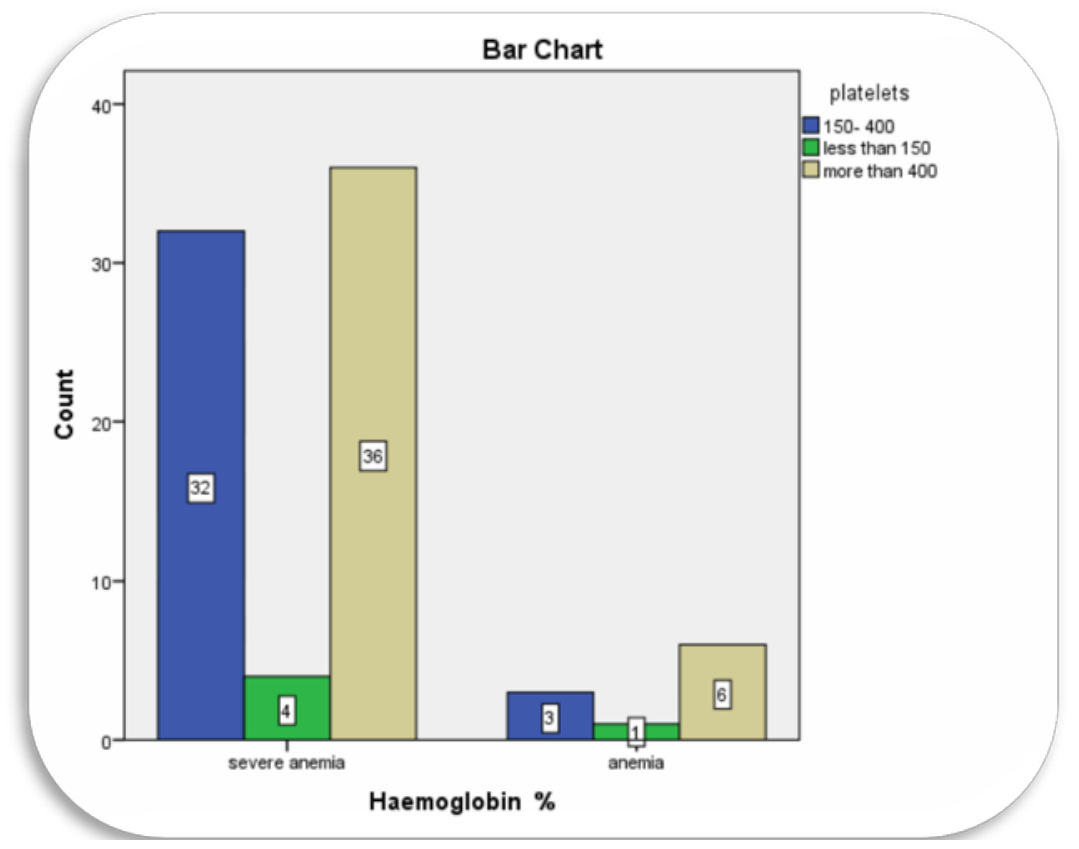

Table 18. Comparison between of hemoglobin and hemoglobin $F$

Hemoglobin \% * Hemoglobin F\%

\begin{tabular}{|c|c|c|c|c|c|}
\hline \multicolumn{6}{|c|}{ Count } \\
\hline & & \multicolumn{3}{|c|}{ Hemoglobin F\% } & \multirow{2}{*}{ Tota } \\
\hline \multirow{4}{*}{ Hemoglobin\% } & \multirow{3}{*}{$\begin{array}{c}\text { severe anemia } \\
\text { anemia }\end{array}$} & $1 \%-2 \%$ & less than $1 \%$ & more than $2 \%$ & \\
\hline & & 8 & 2 & 62 & 72 \\
\hline & & 1 & 0 & 9 & 10 \\
\hline & & 9 & 2 & 71 & 82 \\
\hline
\end{tabular}

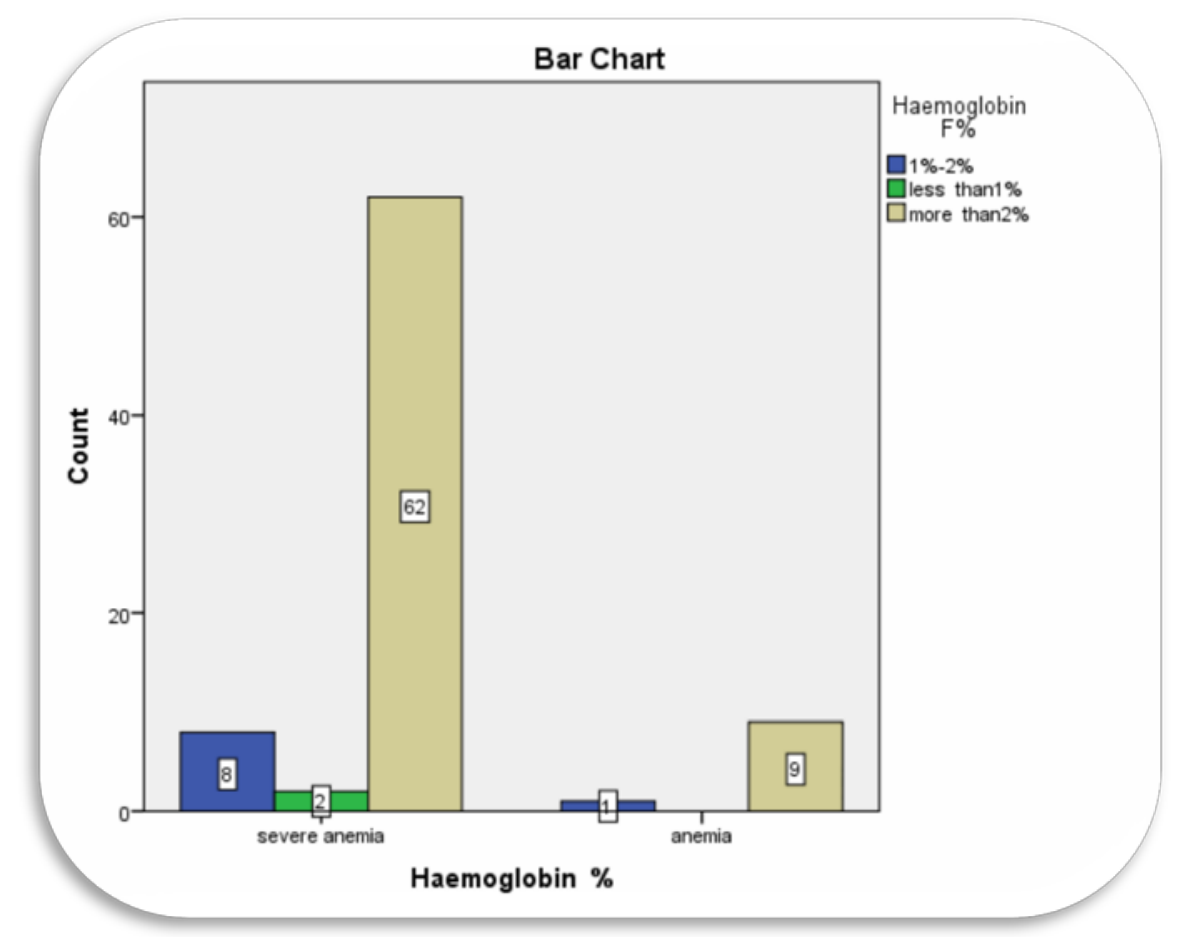


Table 19. Comparison between hemoglobin and hemoglobin A2

\begin{tabular}{|c|c|c|c|c|c|}
\hline \multicolumn{6}{|c|}{ Hemoglobin \% * Hemoglobin A2\% } \\
\hline \multicolumn{6}{|c|}{ Count } \\
\hline & & \multicolumn{3}{|c|}{ Hemoglobin A2\% } & \multirow{2}{*}{ Tota } \\
\hline \multirow{4}{*}{ Hemoglobin\% } & & $2 \%-3 \%$ & less than $2 \%$ & more than $3 \%$ & \\
\hline & severe anemia & 43 & 1 & 28 & 72 \\
\hline & anemia & 8 & 0 & 2 & 10 \\
\hline & & 51 & 1 & 30 & 82 \\
\hline
\end{tabular}

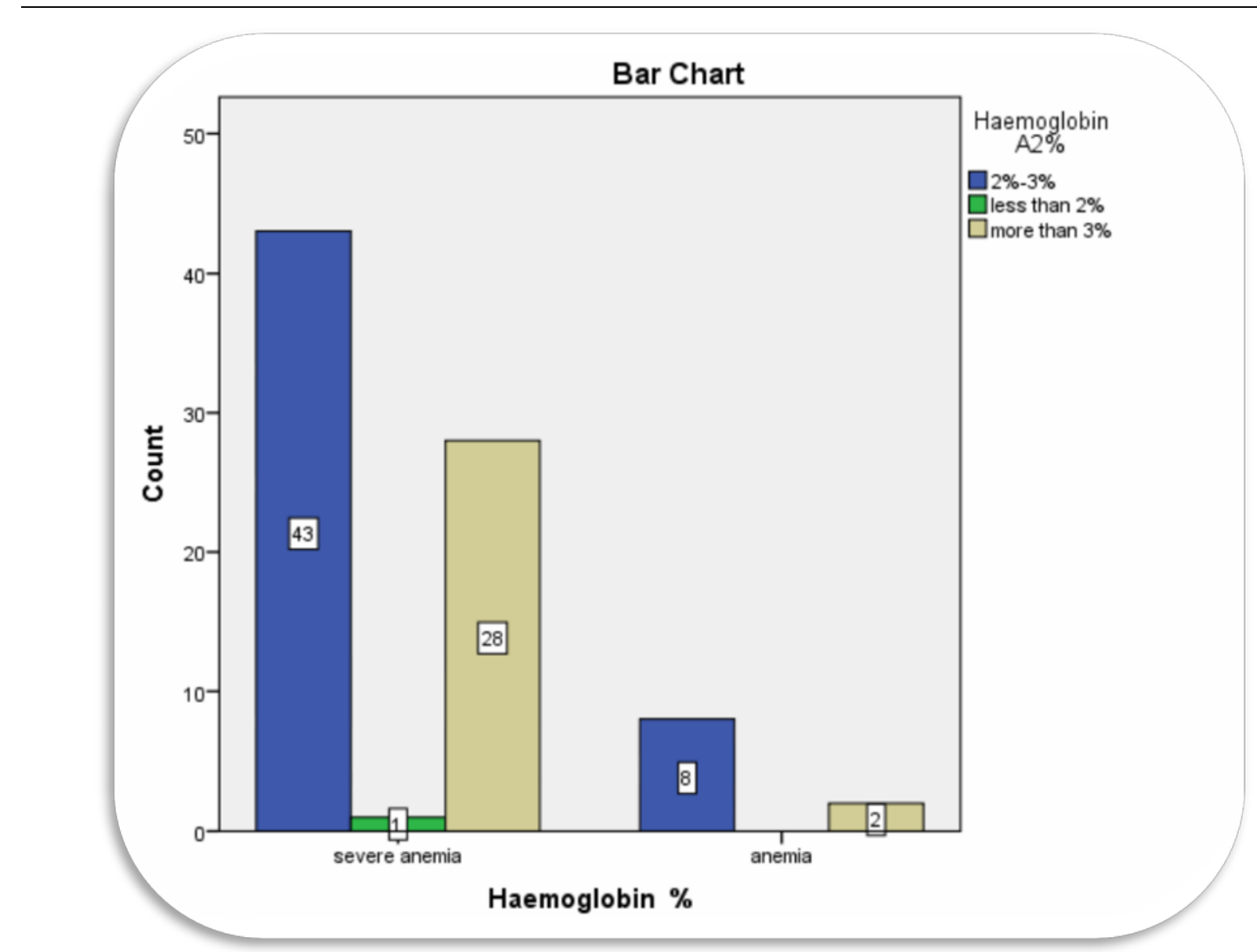

Table 20. Mean and standard deviation of different hemoglobin types

\begin{tabular}{cccccc}
\hline & \multicolumn{7}{c}{ Group Statistics } \\
\hline \multirow{2}{*}{ Hemoglobin F\% } & gender & $\mathrm{N}$ & Mean & Std. Deviation & Std. Error Mean \\
& male & 51 & 2.71 & 0.701 & 0.098 \\
Hemoglobin S\% & female & 31 & 2.84 & 0.523 & 0.094 \\
& male & 51 & 2.00 & $0.000^{\mathrm{a}}$ & 0.000 \\
Hemoglobin A2\% & female & 31 & 2.00 & $0.000^{\mathrm{a}}$ & 0.000 \\
& male & 51 & 1.78 & 0.986 & 0.138 \\
& a. It cannot be computed because the standard deviations of both groups are 0. & 0.170 \\
\hline
\end{tabular}




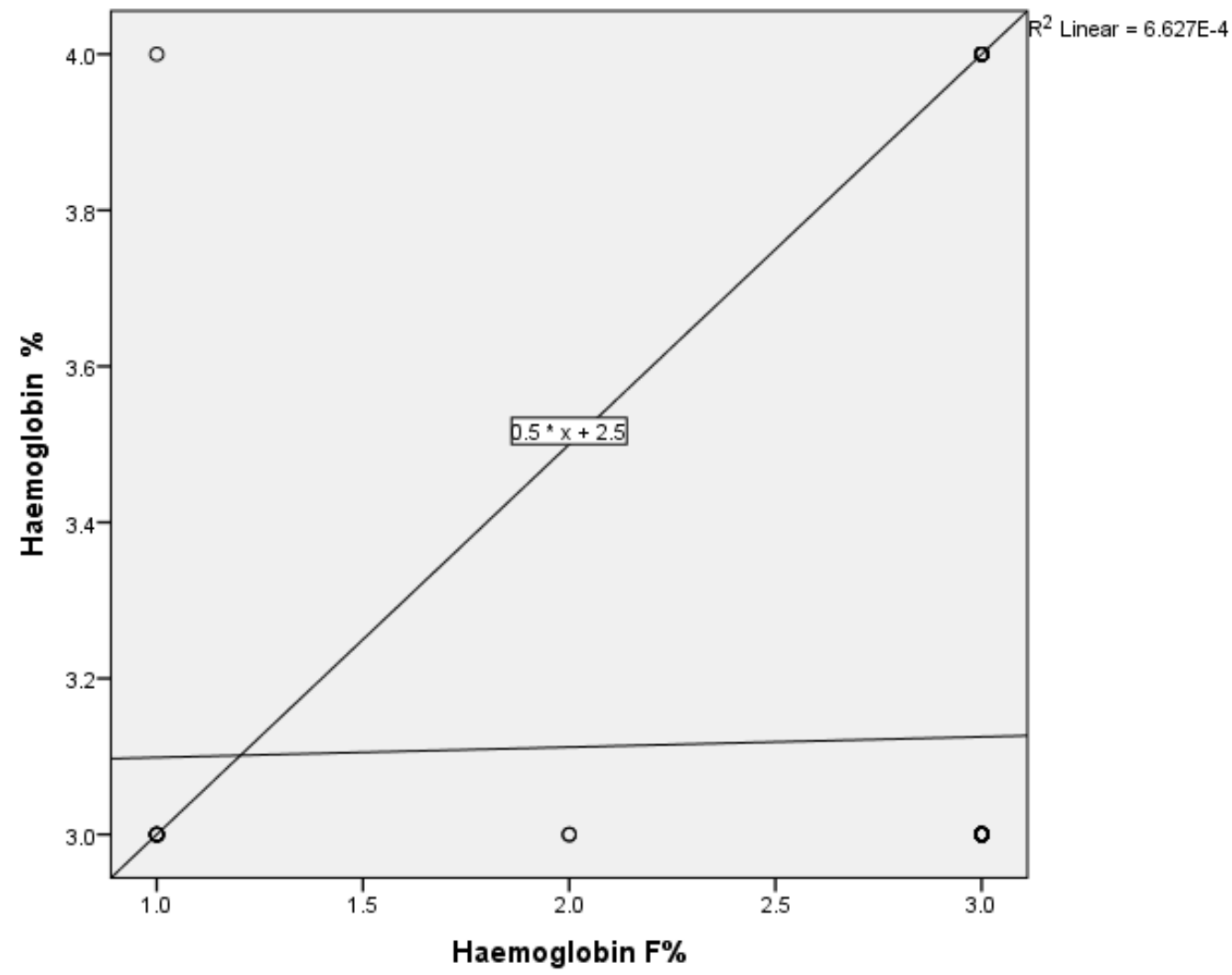

Figure 1. Scatter plot of correlation between hemoglobin\% and $\mathrm{HbF} \%$.

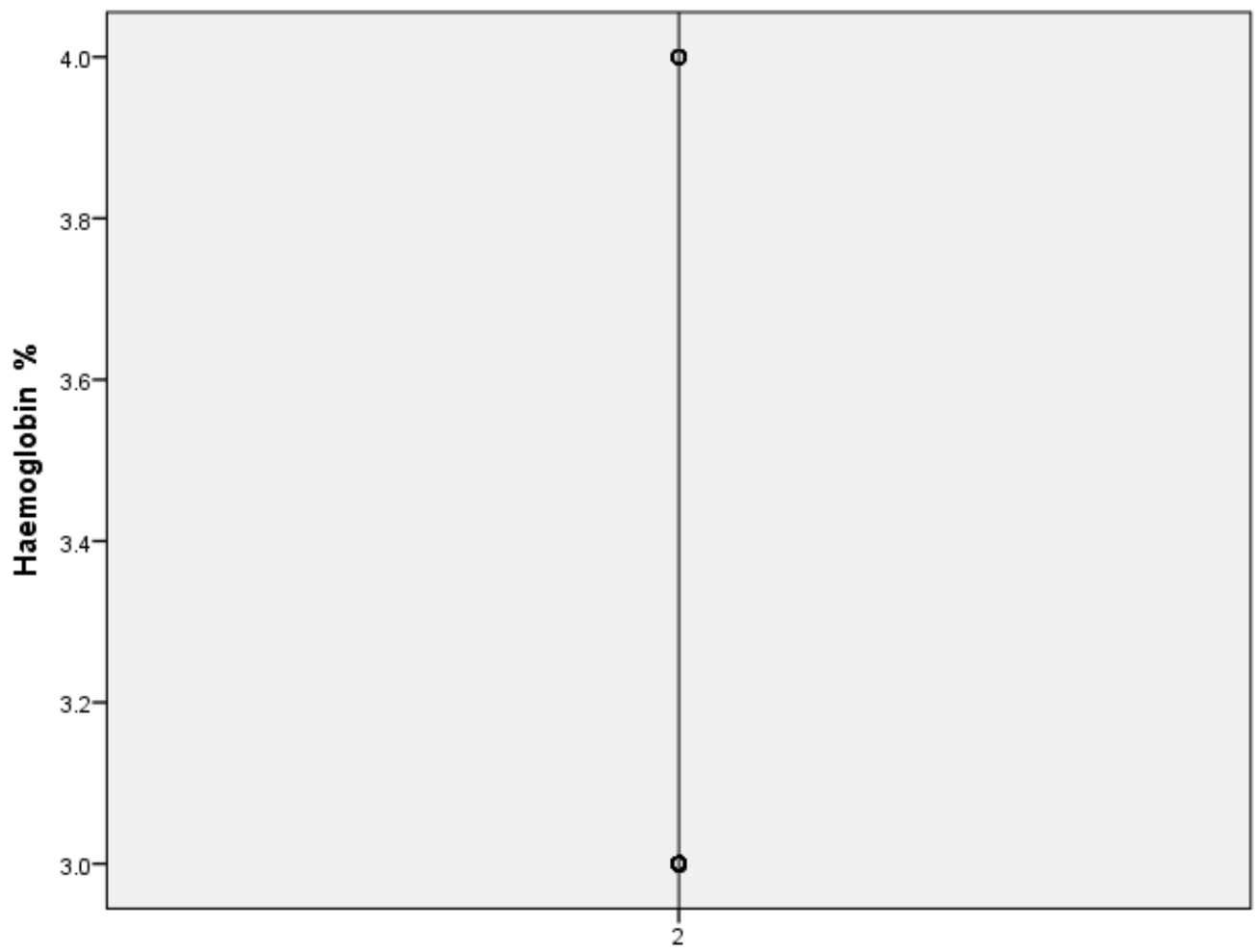

Haemoglobin S\%

Figure 2. Scatter plot of correlation between hemoglobin \% and $\mathrm{HbS} \%$. 


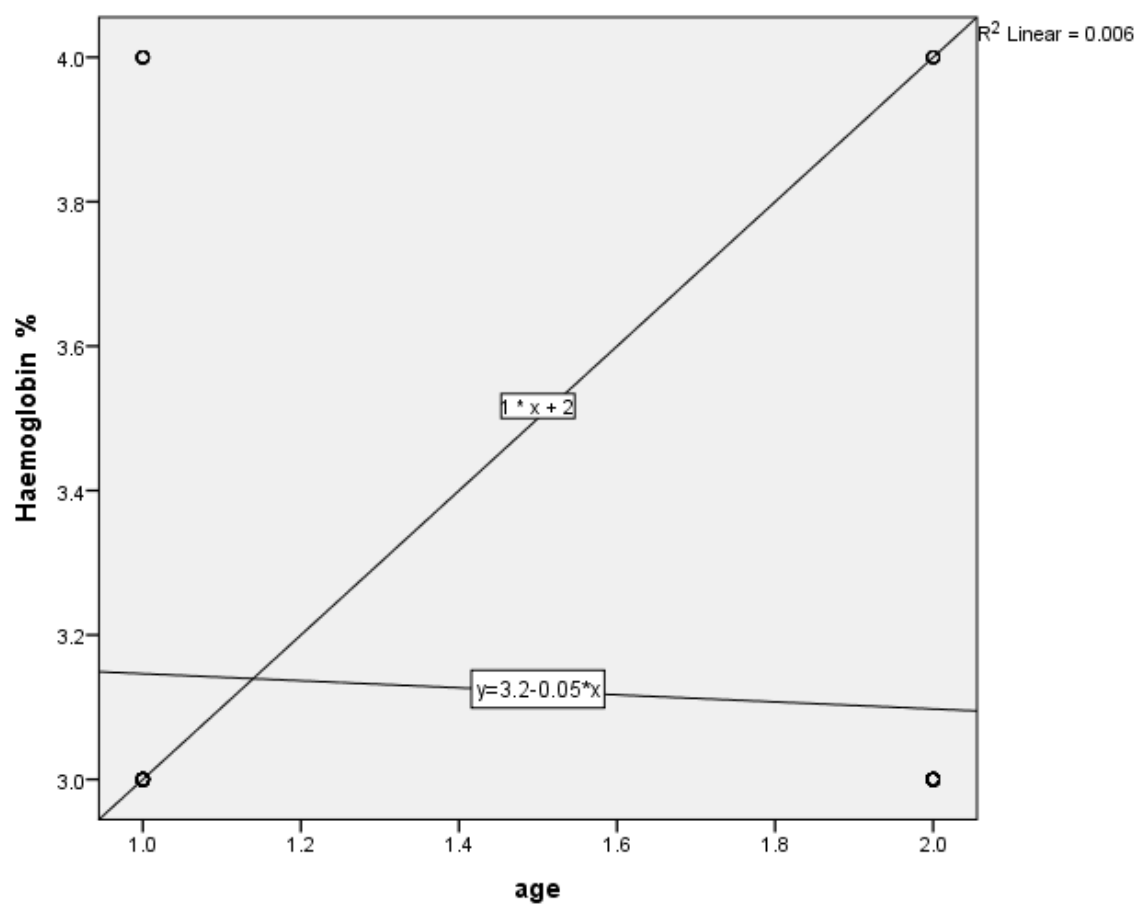

Figure 3. Scatter plot of correlation between hemoglobin\% and age.

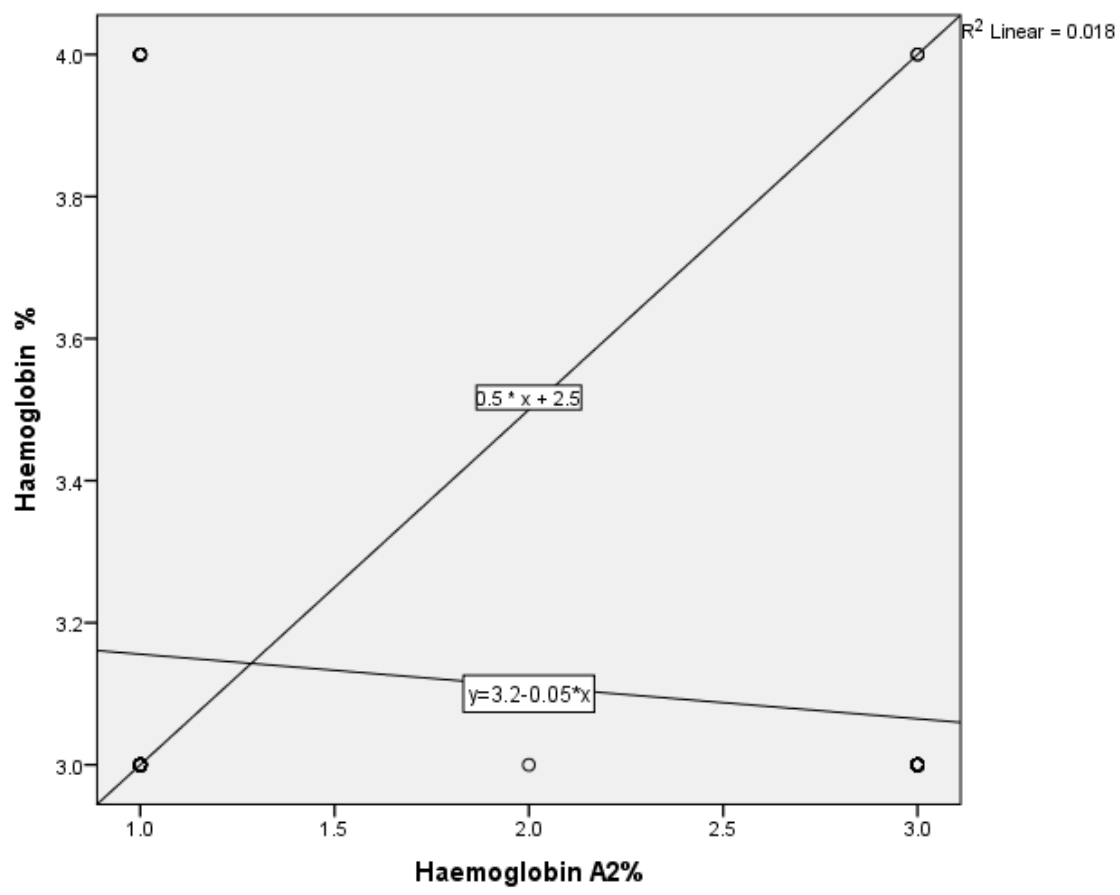

Figure 4. Correlation between hemoglobin and HbA2.

\section{Discussion}

All around world continuous research is conducting in physio chemicals of anticoagulant prosperities, these study well thought out to therapeutically better anticoagulant, multiple targets and safer. This study the mean and standard deviation of $\mathrm{HbF}, \mathrm{HbS}$ and $\mathrm{HbA} 2$ in percentages (2.76 \pm 0.639$),(2.0 \pm 0.0)$ and $(1.74 \pm 0.966)$ respectively in our study. The mean of $\mathrm{Hb} \mathrm{S}$ is the larger indicate that most patients have large level of $\mathrm{Hb} \mathrm{S}$ which is the diagnostic hemoglobin for sickle cell anemia. The mean of $\mathrm{HbF}$ is increased and $\mathrm{HbA} 2$ is also increased. $\mathrm{Hb}$ F, $\mathrm{Hb} \mathrm{S}$ and 
HbA2 show different means and standard deviations in males and females as $\mathrm{HbF} \%$ in males $(2.71 \pm 0.701)$ while in females (2.84 \pm 0.523$) \mathrm{P}$ value (0.098) for males and (0.094) for females, HbA2 (\%) in males (1.78 \pm .0986$)$ while in females (1.68 \pm 0.945$) \mathrm{P}$ value $(0.138)$ for males $(0.170)$ for females, but similar in HbS\% in males $(2.0 \pm 0.0)$ and in females (2.0 \pm 0.0$) \mathrm{P}$ value (0.0) for both sex. Our study agree with study done by [11] in Pakistan it was concluded that The mean of $\mathrm{Hb} \mathrm{S}$ is the larger indicate that most patients have large level of $\mathrm{Hb} \mathrm{S}$ which is the diagnostic hemoglobin for sickle cell anemia and there is the mean of $\mathrm{HbF}$ is increased and $\mathrm{HbA} 2$ is also increased. Hb F, Hb S and $\mathrm{HbA} 2$ show different means and standard deviations in males and females as $\mathrm{HbF} \%$ in males $(2.71 \pm 0.701)$, also agreed with study done by [12] at 2002 in Sudan was found sickle cell anemic patient HbF level about (7+or $-5.6 \%)$, while sickle cell trait patient had $(0.8+$ or -0.5$)$ and sickle cell $\mathrm{HbS} \mathrm{F}$ was found $\mathrm{Hb} \mathrm{F}$ level $(17.4+$ or $-4.2 \%)$ in other research sickle cell anemic patient had $(9.2+$ or $-4.9 \%)$ of $\mathrm{HbF}$ level. As reported by this research that sickle cell anemic patient in their first decade of life (0-10 years) had higher $\mathrm{HbF}(8.2+$ or -5.8$)$ than patient in old age group (above 10 years) HbF level $(2.7+$ or $-1.1 \%)$.

\section{Conclusion}

This study concluded the HbF in sickle cell anemia patients was found to be 85.3 (raised), the HbS in sickle cell anemia patients was found to be $100 \%$ (raised) and the HbA2 in sickle cell anemia patients was found to be $30.5 \%$ (Normal).

\section{List of abbreviations}

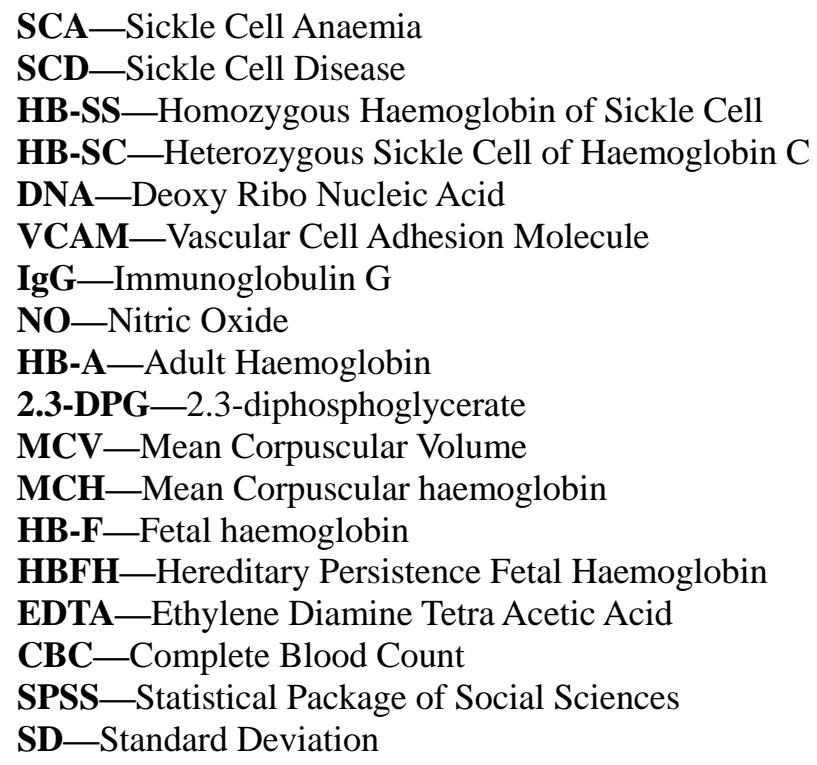

\section{References}

[1] Acquaye, J. K., Omer, A., Ganeshaguru, K., et al. (1985). Non-benign sickle cell anaemia in western Saudi Arabia. Br J Haematol, 60(1): 99-108.

[2] Rdachi, K., Kim, J., Asakura, T., Schwartz, E. (1990). Characterization of two types of fetal hemoglobin: alpha2 G gamma2 and alpha2 Agamma2. Blood, 75(10): 2070-2075.

[3] Adams, R. J., Ohene-Frempong, K., Wang, W. (2001). “Sickle cell and the brain”. Hematology Am Soc Hematol Educ Program, (1): 31-46. Doi: 10.1182/asheducation-(2001).1.31. PMID 11722977.

[4] Dams, R. J. (2007). “Big strokes in small persons”. Arch. Neurol., 64(11): 1567-74. doi:10.1001/archneur.64.11.1567. PMID 17998439.

[5] Aidoo, M., Terlouw, D. J., Kolczak, M. S., McElroy, P. D., Terkuile, F. O., Kariuki, S., Nahlen, B. L., Lal, A. A., Udhayakumar, V. (2002). "Protective effects of the sickle cell gene against malaria morbidity and mortality". The Lancet, Apr 13, 359 (9314): 1311-2.

[6] Aldrich, T. K., Nagel, R. L. (1998). "Pulmonary Complications of Sickle Cell Disease.” In Reynolds, H. Y., Bone, R. C., Dantzker, D. R., George, R. B., Matthay, R. A. Pulmonary and Critical Care Medicine (6th Ed.). St. Louis: Mosby. (1998) pp. 1-10. ISBN 0-8151-1371-4. 
[7] Al-Jam'a, A. H., Al-Dabbous, I. A., Chirala, S. K., et al. (2000). Splenic function in sickle cell anemia patients in Qatif, Saudi Arabia. Am J Hematol, 63(2): 68-73.

[8] Allison, A. C. (2009). “Genetic control of resistance to human malaria”. Current Opinion in Immunology, 21(5): $499-505$. doi:10.1016/j.coi.2009.04.001. PMID 19442502.

[9] Almeida, A., Roberts, I. (2017). "Bone involvement in sickle cell disease”. Br. J. Haematol., 129(4): 482-90. doi:10.1111/j.1365-2141.2005.05476.x. PMID 15877730.

[10] Akinsheye, I., Alsultan, A., Solovieff, N., Ngo, D., Baldwin, C. T., Sebastiani, P., Chui, D. H., Steinberg, M. H. (2018). Blood 7: 118(1): 19-27. doi: 10.1182/blood-2011-03-325258. Epub 2011 Apr 13 Fetal hemoglobin in sickle cell anemia.

[11] Ahmed, S., Saleem, M., Modell, B., Petrou, M. (2002). Screening Extended Families for Genetic Hemoglobin Disorders in Pakistan. N Engl J Med., 347: 1162-8.

[12] Khair, F. M. (2019). The genetic origin of SCD in Sudan haplotype determine of homozygous patient. MD thesis: Khartoum Univ. Br. J. Haematol., 129(4): 482-90. doi:10.1111/j.1365 2141.2005.05476.x. PMID 15877730. 